NBER WORKING PAPER SERIES

\title{
TRANSACTION STRUCTURES IN THE DEVELOPING WORLD: EVIDENCE FROM PRIVATE EQUITY
}

\author{
Josh Lerner \\ Antoinette Schoar \\ Working Paper 10348 \\ http://www.nber.org/papers/w10348 \\ NATIONAL BUREAU OF ECONOMIC RESEARCH \\ 1050 Massachusetts Avenue \\ Cambridge, MA 02138 \\ March 2004
}

We thank many private equity groups for making this study possible by providing the transaction information. Teresa Barger, Richard Frank, Felda Hardymon, Gustavo Herrero, Mario Mahler, Ken Morse, Bruce Purdue, Kanako Sekine, and Camille Tang Yeh introduced us to many groups. Zahi Ben-David, Adam Kolasinski, Jiro Kondo, and especially Yok Nam Ng provided excellent research assistance. We also thank our legal research team: Arturo Garcia de Leon, May Fong Yue Lo, Alexander Nadmitov, Rahul Singh, Michiel Vissier, Agata Waclawik, and Feng Wang, as well as Sridhar Gorthi of Trilegal. We thank Erik Bergloff, Peter Henry, Katharina Lewellen, Roberta Romano, Andrei Shleifer, Per Stromberg, Yishay Yafeh, and participants at presentations at Harvard University, the London School of Economics, the Stockholm Institute for Financial Research, and the Western Finance Association annual meeting for helpful comments. Harvard Business School's Division of Research provided financial assistance. All errors are our own. The views expressed herein are those of the authors and not necessarily those of the National Bureau of Economic Research.

(C)2004 by Josh Lerner and Antoinette Schoar. All rights reserved. Short sections of text, not to exceed two paragraphs, may be quoted without explicit permission provided that full credit, including (C) notice, is given to the source. 
Transaction Structures in the Developing World

Josh Lerner and Antoinette Schoar

NBER Working Paper No. 10348

March 2004

JEL No. F3, G2, K2

\begin{abstract}
While variations in public securities markets across nations have attracted increasing scrutiny, private financings have received little attention. But in developing nations, the bulk of financings are private ones. This paper analyzes 210 private equity transactions in developing countries. We find that unlike in the U.S., where convertible preferred securities are ubiquitous, in developing nations a much broader array of securities are employed and private equity investors often have fewer contractual protections. The choice of security appears to be driven by the legal and economic circumstances of the nation and the private equity group. Investments in common law nations are structured similar to those in the U.S., being less likely to employ common stock or straight debt, and more likely to use preferred stock with a variety of covenants. By way of contrast, in nations where the rule of law is less established, private equity groups are likely to use common stock and own the majority of the firm's equity if the investment encounters difficulties. Private equity groups based in the U.S. and U.K. rely more on preferred securities but also adapt transactions to local conditions. These contractual differences appear to have real consequences: larger transactions with higher valuations are seen in common law countries. These findings suggest that the structure of a country's legal system affects private contracts and cannot easily be undone by (bi-lateral) private solutions.
\end{abstract}

Josh Lerner

Harvard Business School

Rock Center, Room 214

Cambridge, MA 02163

and NBER

josh@hbs.edu
Antoinette Schoar

MIT Sloan School of Management

Finance Department, Room 52-455

50 Memorial Drive

Cambridge, MA 02142

and NBER

aschoar@mit.edu 


\section{Introduction}

The literature on law and finance has highlighted the variation of financial transactions across countries with different legal regimes and the implications for economic outcomes. The majority of these studies, however, have focused on the structure of the countries' public markets. Only a handful of works have studied the effects of legal origins on the functioning of private transactions. But as a growing literature highlights, public markets in developing countries play only a very limited role relative to private transactions in the financing of investments. Figure 1 shows that the overall market capitalization of public firms constitutes only a small fraction of GDP in developing countries, while in developed economies like the US the ratio is above 100 percent. ${ }^{1}$ Overall, there is a greater reliance on private transactions in developing countries than in developed economies. Moreover, from the extensive literature on the role of stock markets across countries (see, for instance, Demirgüc-Kunt and Levine [2001]), we might anticipate that the dynamics of public and private transactions would be quite different. Therefore, it is important to understand how the legal system and the varying enforcement of laws in different countries across the world affect the structure of private transactions.

In this paper, we analyze how contracting choices by private parties respond to their country's legal regime, and if the differences in the contracting environment are

\footnotetext{
${ }^{1}$ We present data for the nine developing countries from which we obtain the bulk of our sample. We observe a few outlier countries that have very small economies but serve as financial centers for the surrounding regions, such as Hong Kong, Singapore, and Luxembourg.
} 
reflected in the real outcomes of the investments: e.g., the valuation and size of the financings. An alternative view might suggest that private parties are able to design contracts in such a way to "contract around" any differences in the legal environment so as to replicate the first-best contracts (see for example Johnson, McMillan, and Woodruff [2002]).

We focus on a specific set of private transactions: private equity investments. We concentrate on these transactions for two reasons: contracts in this area are well documented and second, in contrast to other private transactions, follow a relatively standardized set-up. Private equity transactions represent a relatively modest share of the absolute value of investments made in most developing countries. But we think that they are representative of the legal and economic considerations that private parties face in any contract negotiation. Because of these advantages, we believe that private equity deals are ideal for a comparison of contractual structures and outcomes across countries.

We were able to collect data on the actual contractual relationships between investors and entrepreneurs. Using a sample of 210 transactions from a wide variety of private equity groups, we explore the variation in deal structures across different countries in which the investments are made. This analysis allows us to shed light on the contracting challenges that equity-holders face in countries with different legal regimes.

We also contrast the contracting choices of local private equity groups with those of foreign investors, in particular, U.S.- and U.K.-based organizations. If differences in 
contracting choices reflect the level of the country's financial know-how (or business practices), we would expect that private equity groups based in the nations with the most developed private equity industries would rely on contract provisions that are similar to the ones they use at home, no matter where they invest. If contracting differences are instead driven by underlying constraints in a country's legal system, however, we would expect that even foreign private equity groups will adopt local contracting standards.

We find that legal origin, rule of law, and judicial efficiency are important in explaining cross sectional differences in contracts across countries. While U.K.- and U.S.-based private equity groups are somewhat more likely to write contracts that resemble provisions in their home countries, they do not fully replicate U.S.-style contracts and adjust many provisions to the local environment. Overall, we infer that there is a strong need for groups to "go local" in their contracting choices. In a contemporaneous paper, Kaplan, Martel, and Stromberg [2003] investigate a similar question for a set of high-income European countries. The results in their paper differ from ours quite substantially; since they do not find that private equity groups based in common law based countries tend to "go local." We discuss these results and their relationship to our study in more detail in Section 3.

Several striking patterns emerge from the analysis. Unlike in the United States, where the use of convertible preferred securities is ubiquitous in private equity, substantially different securities are employed in developing nations. More than one-half of the transactions employ common stock, and a subset of deals even uses debt. The 
choice of securities appears to be driven by the legal regime in the country and the nature of the private equity group. Investments in countries with a common law tradition and where the rule of law is well established are far less likely to employ common stock or straight debt, and more likely to employ preferred stock. Similarly, transactions in common law nations are generally associated with greater contractual protections such as more covenants favoring the private equity group. By way of contrast, investors in noncommon law countries, whether with French or socialist legal backgrounds, appear to rely more heavily on obtaining majority control of the firm's equity.

Surprisingly, the composition of boards of directors differs only slightly from that seen in the United States. Common law countries have more substantial representation of founders and managers on the board, while French legal origin countries have more private equity group representatives on the board. These findings suggest that board structure and majority equity ownership may serve as a substitute for contractual protections.

Finally, we investigate if the observed differences in contractual terms across legal regimes also relate to differences in the valuation and size of the investments made. We find that firms' (implied) valuations are significantly higher in nations with better rule of law and those with a common law tradition. Also, countries with better rule of law have significantly higher levels of financing. The difference in financing levels between common law and civil law countries is not significant, but both have higher financing levels than countries with socialist legal origins. While we would like to examine the 
outcome of transactions as well, the relative youth of the investments and the limited opportunities that these private equity groups have had to exit the investments precluded such an analysis.

These systematic differences suggest that contracting parties do face different constraints across legal regimes. This effect is robust even after controlling for the headquarters of the private equity group: our results are not purely driven by common law funds investing in common law countries. In fact, we find that U.S.- and U.K.- based funds invest in a wide range of countries with different legal backgrounds.

A natural question is whether private equity groups vary their contracting choices across countries because of differences in investor protection and enforcement of laws, or because of direct constraints on the type of contracts that can be written. For instance, it would not be a surprise to see little reliance on convertible preferred securities, if the security law in the country prevents the use of convertible preferred altogether. We addressed this concern by seeking to understand the legal curbs on private equity groups in the nine nations most frequently represented in our sample. We do not find evidence that the results are "hard-wired" by constraints on the contract space; our findings hold even when we exclude those countries where the private equity groups face a constrained choice set. 
The plan of this paper is as follows. Section 2 briefly reviews the earlier literature. Section 3 describes the construction of the data set. The analysis is in Section 4. The final section concludes the paper.

\section{Related Literature and Its Implications}

Our analysis is at the intersection of two bodies of work. First, an extensive "law and finance" literature in recent years has highlighted the importance of a nation's legal origins in determining the structure and efficiency of its financial (and other) institutions. Many institutions in developing countries are not indigenous, but rather have been transplanted during colonization: for instance, English colonies widely adopted common law-based legal systems, while colonies of French legal family nations adopted civil law codes. A variety of papers have documented the importance of legal origin, starting with La Porta, Lopez-de-Silanes, Shleifer, and Vishny [1997, 1998]. They identify legal origin as a crucial determinant of the laws governing the protection of outside investors from expropriation by corporate insiders, with common law systems providing better protection than civil law ones. They also show that better investor protection is strongly associated with broader and more valuable capital markets, a faster pace of public offerings, more dispersed ownership of public firms, and other indicators of financial development. Subsequent research shows that civil law countries exhibit other problematic features, such as heavier government intervention in economic activity (La Porta, Lopez-de-Silanes, Shleifer, and Vishny [1999]) and more burdensome regulation of new business entry (Djankov, La Porta, Lopez-de-Silanes, and Shleifer [2002b]). 
The second body of related empirical literature examines the structure of venture capital investments. For a detailed review of theoretical literature on the structure of these transactions, the reader is referred to Kaplan and Stromberg [2003]. This work, such as Gompers [1995], Gompers [1998], and Kaplan and Stromberg [2003], has largely focused on the United States. The authors emphasize the crucial impact of the degree of uncertainty surrounding the transaction. In settings where there is substantial uncertainty surrounding the new venture, greater informational asymmetries should be present and the contribution of the entrepreneur should be more critical. In these settings, private equity investors will need to take steps to protect themselves from agency problems. These analyses will serve as an important benchmark for us. But our focus here will not be on the differences between certain industries and types of investments, but on the variation across different countries and legal regimes.

A couple of earlier academic studies have explicitly compared private equity investments across a number of developing countries. Jeng and Wells [2001] analyze the determinants of venture capital for a panel data set of 21 (mostly developed) countries. They find that IPOs are the strongest driver of venture capital investing, particularly laterstage investments. Early-stage venture capital investing, however, is relatively unaffected by IPO activity but negatively impacted by labor market rigidities. Cumming and MacIntosh [2002] examine the types of transactions funded and exit routes employed in 12 Asian nations. They argue that the legal regimes affect the types of investments selected and the way in which the private equity groups exit their holdings, but not the level of the returns the investors enjoy. 
The paper that follows our analysis most closely is Kaplan, Martel, and Stromberg [2003]. The authors focus on private equity contracts in a number of higher-income European countries. Parallel to our analysis, they find that contracting choices vary across countries with different legal regimes. Interestingly, however, when controlling for the legal origin of the private equity group, they do not find the "going local" effect that we document for our sample of developing countries. Instead, they show that most of the variation between common law and civil law contracts can be explained by the fact that U.K.- and U.S.-based private equity groups use contracts that are very similar to the ones they employ in their home countries. It is possible that the higher sophistication of the judicial system in these countries allows private equity groups to experiment with contracts that are different from those customarily employed. One might also conjecture, however, that a perceived sense of similarity between the U.S. and Continental Europe led investors in some cases to make contracting choices that might ultimately be very difficult to enforce in these countries.

\section{The Sample}

We constructed the sample by approaching a number of private equity groups active in developing nations. ${ }^{2}$ We asked each to provide us with the investment

\footnotetext{
${ }^{2}$ According to the World Bank, developing nations are those countries that have either low- or middle-level per capita incomes; have underdeveloped capital markets; and/or are not industrialized. It should be noted, however, that the application of these criteria is somewhat subjective. For instance, Kuwait appears on many lists of developing nations despite its high per capita gross domestic product. The reason for its inclusion lies in the income distribution inequality that exists there, which has not allowed it to reach the general living standards of developed countries. For the purposes of this paper, we take
} 
memorandum or private placement memorandum of as many transactions as possible, as well as the associated stock purchase agreements, preferred stock agreements, and any other documents associated with the structuring and governance of the transaction. We asked groups to choose a representative array of transactions, along dimensions such as the type of deal, the location and industry of the firm, and the success of the transaction. Given the lack of any comprehensive database of private equity transactions in the developing world, it was difficult to verify the completeness of the sample.

We deliberately attempted to recruit as diverse an array of private equity funds as possible. To this end, we complemented our own direct contacts (which were disproportionately those of large and U.S.-based groups) with those of four international development organizations, which tend to invest in smaller funds based in developing countries. These organizations encouraged funds in which they were invested to provide data as well.

Table 1 summarizes the sample. The 210 transactions are from 28 private equity groups, who contributed between 2 and 21 deals for our sample. The transactions occurred between 1987 and 2003, with the bulk of investments having been made between 1996 and 2002. We first assigned the industries to detailed classes. Because a number of these industries shared common characteristics (e.g., a considerable number of

an expansive view of what constitutes a developing nation, and simply eliminate any transactions taking place in the 24 nations who were original members of the Organisation for Cooperation and Development or joined within the first fifteen years of its creation (i.e., through the addition of New Zealand in 1973). 
transactions were in traditional manufacturing industries that are characterized by little $R \& D$ and few intangible assets), we consolidated the categories. The industries include a broad array, from food to information technology.

We classified the transactions by type using the definitions in European Venture Capital Association [2002]. The investments are dominated by expansion transactions (which typically entail the provision of capital in growing firms that are more mature than the typical venture-backed concern), as well as venture capital and buyout transactions. The other transactions are, as discussed above, less commonly seen in developed nations, such as investments in privatizations, initial public offerings, and acquisitions.

The nations represented are summarized in the final panel of Table 1 . Thirty distinct countries are represented, from Africa, the Americas, Asia, and Eastern Europe. No single nation or region dominates the sample.

From Panel A of Table 2, we see that the average GNP per capita for the countries in our sample is $\$ 2142$ per year. Moreover, $27 \%$ of the investments included in our study are based in countries that have British legal origins, $30 \%$ in countries that have French legal origins, and $42 \%$ are in former socialist countries. By way of comparison, $56 \%$ of the investments included in this study are funded by private equity partnerships that are based either in the U.S. or U.K. While U.K.- and U.S.-based partnerships in our sample make the majority of investments in countries with a British legal origin, we find that they also invest in a large fraction of deals that are not based in common law countries. 
This heterogeneity is important, since it will allow us to analyze whether a given partnership adjusts the contract terms in response to the environment of the country where the deal takes place.

To get a deeper understanding of the extent to which the choices of the private equity groups were driven by the laws in each nation, we research the legal factors affecting private equity groups in the nine nations most frequently represented in our sample. We recruited a number of L.L.M. candidates at Harvard Law School from these respective countries. We asked them to research the factors influencing private equity funds in their home country, through an examination of the relevant texts and interviews with practitioners who work in private equity in the respective countries. This information is presented in highly summarized form in the Appendix. ${ }^{3}$

In a study along these lines, selection biases are an almost inevitable consequence. (At least somewhat ameliorating this concern, we obtained transactions from a significant number of groups.) It is likely that the private equity groups that participated in this study are more Western-oriented and sophisticated than their peers. The presence of these biases make the substantial differences that we see from the U.S. patterns even more striking.

\section{Analysis}

\footnotetext{
${ }^{3}$ More detailed documentation of the key legal considerations for each of these countries can be obtained from the authors.
} 
We proceed in several steps. We first examine the broad characteristics of the transactions. We then consider the types of securities employed. We next turn to understanding the allocation of equity ownership. We consider several dimensions of how the control over the company is allocated. We look at the size and valuation of the investments. Finally, we look at the correlations between these various contractual features.

\section{A. Summary Statistics}

Panel B of Table 2 provides an initial overview of the transactions. The differences between this sample and U.S. transactions are striking. We will highlight several examples. In the United States, private equity transactions are dominated by those employing convertible preferred stock: nearly $80 \%$ of the transactions in Kaplan and Stromberg's [2003] sample of 200 U.S. deals rely on this security. ${ }^{4}$ Common stock is quite rare, found in only a little more than $10 \%$ of the U.S. deals. In our sample, the transactions are dominated by common stock: fully $54 \%$ of the developing country transactions employ these securities. Convertible preferred stock is only encountered in $21 \%$ of the deals. ${ }^{5}$

${ }^{4}$ It should be noted that Kaplan and Stromberg's sample includes only venture capital transactions, which would encompass transactions described as "venture capital" and "expansion" transactions in the developing world. (The category of "expansion" deals is not frequently employed in the U.S.) Legal texts (e.g., Bartlett [1995]), however, suggest we would observe similar patterns if we examined all U.S. private equity transactions.

${ }^{5} \mathrm{We}$ tried as best as possible to avoid any bias in our coding of contractual terms that are purely based on differences in contractual language. For example, any security structure that has payoff streams equivalent to a convertible preferred would be classified as such, even if the contract did not explicitly use that term. 
Second, many of the protections commonly employed by venture capitalists in the U.S. are rarely found here. Kaplan and Stromberg [2003] find that venture capitalists obtain redemption rights in $84 \%$ of the transactions, anti-dilution protection in $95 \%$ of deals, and founder vesting requirements in $42 \%$ of transactions. The corresponding shares in our sample are $31 \%, 27 \%$, and $5 \%$.

Finally, the structure of the boards differs little from that seen in the U.S. The mean U.S. transaction has a board with 6.2 members, of which two seats were allocated to the founders and managers and two-and-a-half to venture capitalists (Kaplan and Stromberg [2003]). The patterns here are similar, though we see a slightly greater representation of founders and managers on the boards.

In Table 3, we include a number of representative provisions that reflect some of the interesting differences with the private equity contracts typically observed in the U.S. Two aspects are particularly interesting. First, the lack of liquid capital markets in these countries means that the choice of exit option is very different from the U.S. For example, many private equity contracts in our sample of emerging market deals implicitly—but often explicitly—state that the preferred exit option is a "sale to a strategic buyer." In eight cases, a potential strategic buyer even invests alongside the private equity group in the financing transaction. Also, we see a much greater tendency to rely on large dividend payments out of profits when exit through an IPO or sale is not possible. 
A second interesting feature is the reliance on parent companies to either enforce or back up deals. In many developing countries, ownership structures of firms are much more complicated and pyramidal than in the U.S. Often a company is ultimately controlled by a parent company that holds important control rights (but not always cash flow rights of similar magnitude). We see that in a few instances, private equity groups use the parent companies to back the loans of the subsidiary. Moreover, in seven cases we see that the parent provides a potential exit strategy for the private equity group: the investors are allowed to put back the stock they own to the parent, whose shares are probably much more liquid (and potentially less volatile).

\section{B. Regression Analysis}

The econometric analysis throughout the paper employs a similar structure: we begin by analyzing the provisions in the transactions using dummy variables for each provision.

The main explanatory variables we are interested in are the countries' legal origin and their contractual and economic circumstances surrounding the private equity investments. We also control for industry, deal type, and year fixed effects. ${ }^{6}$ While we

\footnotetext{
${ }^{6} \mathrm{We}$ use dummy variables for the observations in three time periods in the reported regressions: the years 1993 to 1997, 1998 to 2000, and 2001 to 2003. These periods correspond respectively to the years when many institutions made initial investments into private equity funds focusing on leveraged buyouts in developing nations, the growth of venture capital funding in these nations, and the recent sharp fall-off in venture capital and private equity activity there. The results are robust to the use of dummy variables for
} 
believe that the use of these control variables is necessary to avoid potential biases, they come at a cost: the large numbers of dummy variables play havoc with the results when we employ a non-linear specification. Thus, while the univariate nature of many of the dependent variables might suggest the use of a logit specification, we will simply report ordinary least squares results. (Results employing logit specifications without industry dummy variables are generally very similar.)

We also anticipate that the following dimensions may be important in affecting contracting choices due to underlying differences in the nature and development stage of a country, independent of the country's legal origin. Therefore we include a number of time-varying control variables:

- The extent of economic development in the nation. The nature of the opportunities that the private equity investors face may differ substantially with the degree of development of the nation, which will in turn be a function of its initial resources and many other considerations. These environmental factors may affect both the size and nature of available financing opportunities, and in turn influence the contracting structures as well. We employ the per capita gross national product (in current dollars) averaged over the 1990s.

- The extent of the rule of law in the nation. Since the relationship between a private equity investor and an entrepreneur is fundamentally a contractual one, the manner and ease with which property rights can be protected in the courts is a

each year, as well as to the use of controls measuring the annual level of private equity fundraising worldwide and of foreign direct investment into developing nations. 
critical measure. As a result, the types of arrangements entered into between these parties should differ. The measure we employ, originally developed by the Fraser Institute, was employed in Acemoglu, Johnson, and Robinson [2001]. This index is a rating on a scale from zero to ten, with the greater the equality of parties and the access to a non-discriminatory judiciary, the higher the score. ${ }^{7}$

- A measure of judicial efficiency. An alternative measure of the legal protection that firms can expect in a given country is the index of judicial efficiency. It represents an assessment of the "efficiency and integrity of the legal environment as it affects business, particularly foreign firms." It may be "taken to represent investors' assessment of conditions in the country in question." This measure focuses more on the enforcement of laws rather than the way the law is written. It employs a scale from 0 to 10 , with lower scores representing lower efficiency levels. This measure is produced by the country risk-rating agency International Country Risk (ICR), and has been previously used in Djankov, La Porta, Lopezde-Silanes, and Shleifer [2002a].

Throughout, we employ logarithms of the non-univariate dependent and independent variables. Our rationale is that the impact of many of the measures is likely to be non-linear. For instance, the shift from $\$ 500$ to $\$ 600$ in per capita GNP is likely to be far more meaningful than one from $\$ 8500$ to $\$ 8600$.

${ }^{7} \mathrm{We}$ compared this measure to the index of property right protection developed in the 1997 Index of Economic Freedom, which was used in La Porta, Lopez-de-Silanes, Shleifer, and Vishny [1999]. The correlation coefficient between the two measures is high (0.82), but the rule of law measure was available for a considerably larger number of countries. 


\section{B1. Security Types}

We begin the econometric analyses by examining the types of securities employed. Panel A of Table 4 shows that common stock is less frequently employed in nations with a British legal origin. This pattern continues to hold when we add controls for whether the private equity group is based in a common law country. Thus, the observed pattern is not simply a consequence of the fact that investments in common law countries are disproportionately made by funds based in nations such as the United States. Meanwhile, groups based in the U.S. and U.K. use common stock less often. (The results do weaken when we employ a measure of judicial efficiency as well, which reduces the sample size.) A similar pattern is seen in the use of straight debt in Panel B: such a security is much less frequently employed in common law countries and by U.S.and U.K.-based funds.

The reverse pattern is observed in Panel C of Table 4, where we examine the use of preferred stock. This security, so ubiquitous in the U.S., is disproportionately seen in nations with British legal origins and in transactions undertaken by American and British private equity groups. The security is also employed when the index of judicial efficiency is higher. (Nations with French legal origins are also significantly more likely to employ such provisions in this regression, but not in other specifications.)

We then repeat this analysis while excluding any countries that have legal restrictions on the type of securities that can be used in private equity transactions. The 
idea is that we want to prevent our results from being "hard wired" by legal constraints in different countries. For example, in the case of the Peoples Republic of China, domestic as well as foreign firms can only get permission to use security structures other than common stock in very exceptional cases. We find that the results presented above are qualitatively unchanged when excluding nations from the sample that have any constraints. This suggests that our findings reflect the investors' contracting choices and not just the constraints imposed by different legal regimes.

\section{B2. Allocation of Equity}

We then turn to the allocation of equity ownership. Panels A and B of Table 5 examine the allocation of control of the company's equity to the private equity group. The dependent variable is a dummy that takes on the value one if the private equity investors have at least $50 \%$ of the equity, calculated at their maximum and minimum stake respectively. (The size of the stake can vary, whether due to contingent clauses or the vesting of founder and manager shares.) Panel $\mathrm{C}$ of Table 5 analyzes the magnitude of the difference between the largest and smallest ownership stake assigned to the private equity group.

The key findings are as follows:

- When the rule of law is more established, private equity groups are less likely to have control of the firms' equity in the maximum stake scenario as well as the minimum stake scenario. When we add a judicial efficiency measure as well, it becomes consistently negatively significant, while the coefficient on the rule of 
law variable declines. This finding is consistent with a theme that emerged from our conversations with private equity groups. The groups highlighted that they placed much greater emphasis on having controlling blocks of the equity of firms in nations with poor property rights, particularly during periods when performance was troublesome.

- Second, investments in nations with a common law legal tradition are more likely to have control under the maximum scenario. Private equity groups based in the U.K. and U.S. are similarly more likely to have control stakes in the maximum control scenario, but less likely to have controlling stakes in the minimum control scenario. This suggests a greater reliance of these groups on variations in ownership control as an incentive mechanism for founders and managers, as well as a protection in bad states, perhaps due to their greater ability to enforce contingent contracts. (For a formal treatment of this point, see Gennaioli [2003].) This idea is also reconfirmed in the analysis of differences between maximum and minimum ownership stakes in Panel C of Table 6. Again we find that U.K. legal origin countries have much greater variation between the maximum and minimum control stakes than civil law countries.

- Finally, investments in countries with a higher GNP per capita are more likely to allow the private equity group to have control in the maximum and minimum stake scenarios, as well as to use contingent securities.

\section{B3. Control Rights}


The next four tables analyze what we term control rights: provisions that affect the prerogatives of the private equity investors or the managers they finance. Here several consistent themes emerge. Transactions in common law countries are more likely to offer protections for the private equity investors. We also find that private equity groups based in the U.K. and U.S. demand more protections than others. Finally, deals in wealthier nations are generally more likely to include investor protections.

More specifically, we find the following results for these contract provisions:

- First, in Table 6 we analyze the existence of anti-dilution provisions, the right to have some compensation if subsequent financing is done at a lower price, and provisions for automatic conversion. Lawyers typically interpret the latter as protecting the lead private equity investor against individual or smaller private equity investors, who may seek to "hold up" an IPO or acquisition by refusing to convert their shares. It should be noted that while many nations give investors rights to preserve their pro rata equity share in future financings, anti-dilution provisions give far greater protections to the private equity groups. ${ }^{8}$ We find that investments in nations with a common law tradition tend to have more protections, as seen in the analyses of the anti-dilution provisions and automatic conversion provisions. Similarly we find that higher per capita GNP generally is related to a higher degree of protection against anti-dilution and automatic

\footnotetext{
${ }^{8} \mathrm{We}$ were able to identify one nation that legally prohibited dilutive financings (Brazil). The results continued to hold when we excluded this nation from the sample.
} 
conversion provisions. We also observe that U.S.- and U.K.-based private equity groups tend to rely more heavily on these protections.

- Table 7 looks at the extent to which the ability of founders and management to liquidate their stake is constrained, either through provisions regarding vesting (the staged provision of shares to management) or explicit restrictions on stock sales. Because we did not always receive the agreements between the companies and managers from the private equity groups, we can measure this phenomenon in a less thorough manner than the other transaction characteristics. ${ }^{9}$ The results regarding these contract dimensions did not show any significant patterns. One possible explanation was the small sample size for this analysis.

- Table 8 investigates the structure of the board as specified in the stock purchase agreements, examining the overall board size as well as the seats assigned to the private equity group and founders and managers. We see that common law nations tend to have larger boards with greater representation of founders and managers on the board. One possible interpretation of this finding is that the effectiveness of other methods of enforcing investor rights is sufficiently large, so that the addition of other board members, and the possible loss of control entailed, is less critical.

\footnotetext{
${ }^{9}$ Again, the results continued to hold when we excluded China, where managerial equity holdings are sharply limited.
} 
- Finally, Table 9 looks at supermajority provisions. These provisions regarding supermajority approval (where some fraction greater than one-half of the members must approve a decision) appear nineteen different places in these agreements. We score these clauses from zero to three, with a higher score representing a more stringent supermajority clause. ${ }^{10}$ We simply sum these separate scores. We find that investments in common law nations are more likely to employ supermajority provisions, while investments in civil law countries are less likely to include them in the contracts. Similarly, deals in richer nations rely more frequently on supermajority provisions. A puzzling finding in our data is the reduced use of supermajority provisions in countries with better rule of law. Countries with better judicial efficiency, however, tend to rely more frequently on these provisions (though this result is only significant at the $10 \%$ level).

\section{Financing Characteristics}

A natural question, suggested by La Porta, Lopez-de-Silanes, Shleifer, and Vishny [2003], relates to the consequences of these investment choices. Ultimately, we would like to examine this question by looking at the relationship between transaction structures and outcomes of the investments. Given the relative recentness of most of the investments, and the limited ability that investors have had to exit private equity investments in developing countries in recent years, such an analysis would be premature.

\footnotetext{
${ }^{10}$ Zero represents a case with no such provision. Cases where a supermajority of the shareholders must approve the step are coded as one; instances where a supermajority of the board must approve are coded as two. Three denotes cases where a supermajority of both equity-holders and board must approve.
} 
Instead, we simply focus on the characteristics of the financial transaction: the size of the financing and the associated valuation.

When we look at the size of the financing in Panel A of Table 10, we see that (not surprisingly) investments in firms with higher sales and in nations with greater per capita GNP involve larger disbursements of capital. In addition, transactions in common law countries and by private equity groups based in the U.S. and U.K. are larger in magnitude, though the effects are less consistent.

When we turn to valuations, ${ }^{11}$ we find again that firms with larger revenues are associated with higher valuations. Both countries rooted in the British and French legal families are assigned higher valuations, though the magnitude of the effect is considerably larger and more consistently significant in the common law nations. Higher GNP per capita and American and British private equity investors are associated as well with higher valuations. Finally, the index of judicial efficiency is strongly associated with higher valuations. All these findings suggest that the differences in legal regime affect not just the structure of these transactions, but also have real effects on firms' value. $^{12}$

\footnotetext{
${ }^{11}$ Following Gompers and Lerner [2000], we examine the "post-money" valuation: the valuation of the firm after the completion of the financing transaction. As noted above, the results remain robust when we add additional controls for the characteristics of the firms and transactions.

${ }^{12}$ Our interpretation of these results must be somewhat cautious since we only observe realized transactions. Common law countries might have better protection of shareholder rights and we would therefore expect to see higher valuations for a given investment. Investments that are completed in non-common law countries, however, might be
} 


\section{Correlation of Different Contract Parts}

To this point, we have been analyzing each of the contractual features in isolation. In the final analysis, we investigate the correlation structure between different parts of the individual contracts. Our goal is to understand whether security structure, ownership stake, and other control provisions are used as complements or substitutes in financial contracting. For example, we could imagine that deals where the private equity group takes a common stock position rely more heavily on having a controlling ownership stake. In that case, even though the security structure per se does not give the private equity group as much control rights as a preferred security would, the fact that the group has the majority ownership stake could be seen as an alternative control mechanism.

To undertake this analysis, we regress each of the variables of interest on each other, as well as controls for the logarithm of gross national product, the rule of law index, and the dummy variables for the year, industry, and deal type. In Panel A, we look at the correlation between various contractual provisions; in Panel $\mathrm{B}$, we examine the correlation with financing size and valuation. In each cell we report only three sets of numbers: each line represents the coefficient of a regression of a contract part on a different provision of the contract. We repeat these regressions for the entire sample, for the common law nations only, and for the other nations.

particularly promising. Thus, there may not be as many differences in the intensive margin, i.e. the observed amount of financing, as along the extensive margin (the number and types of deals that are done). As discussed before, it is impossible for us to construct an exhaustive sample of deals for these countries, which makes it very difficult to draw any conclusions about the extensive margin. 
Table 11 shows a number of results from this exercise:

- First, we see that while the use of debt and debt-like securities is positively related to the presence of common shares, we find a negative correlation between common and preferred stock.

- We find that preferred stock offerings are more likely to employ other control provisions such as anti-dilution and automatic conversion provisions. These effects are strongest in common law nations. These features are generally negatively associated with common stock.

- We find a strong positive correlation between the maximum ownership stakes that the private equity group obtains and the use of debt. The correlation between the maximum ownership stake and the use of preferred securities is inconsistent and rather small. If we look at the correlation of a private equity group's minimum ownership stake with the other contract parts (not reported), the difference between common and preferred stock deals becomes even stronger.

- Common stock is correlated with smaller deal sizes and valuations. Contractual provisions that protect investors (e.g., anti-dilution and automatic conversion provisions) are associated with higher valuations, but this effect seems confined to common law nations.

Overall, these results suggest that contracts differ systematically in the way they aim to provide investors with control rights. While preferred security structures and the use of control provisions such as anti-dilution clauses are generally used as complements, common share deals and debt-like securities rely more heavily on controlling ownership 
stakes, and much less frequently on other control provisions. Taken together, these results suggest that contracts either seem to follow a structure that is fairly reminiscent of U.S. contracts-i.e., preferred type securities accompanied by a number of control provisions - or rely on debt or common stock securities without many other control provisions.

\section{Conclusions}

While variations in public securities markets across nations have attracted increasing scrutiny, the determinants of the variations in private financings have attracted much less attention. This neglect is particularly worrisome in developing nations, since the bulk of financings in these markets are private ones.

This paper seeks to understand how the origins of legal regimes, as well as differences in the enforcement of these laws, affect private transactions in developing nations. We focus on a well-documented and reasonable systematized set of transactions: investments by private equity groups into entrepreneurial or restructuring firms. This paper analyzes a sample of 210 transactions from a wide variety of private equity groups in developing countries. We assess deal structures, and how they vary with the nature of the nations in which the investments are made.

We find a number of interesting patterns:

- Unlike in the United States, where the use of convertible preferred securities is ubiquitous, in developing nations a much broader array of securities are 
employed. Protections of private equity investor rights that are standard in the United States are encountered far less frequently.

- The choice of security employed appears to be driven by the circumstances of the private equity group and the nation. Investments in common law nations and by private equity groups based in the U.S. and U.K. are considerably less likely to employ common stock or straight debt, and more likely to employ preferred stock.

- In nations where the rule of law is less well established, private equity groups emphasize equity protection. They are likely to make the size of their equity stakes contingent on the performance of the company and to have the majority of the firm's equity if the investment encounters difficulties.

- Transactions in common law nations are generally associated with more contractual protections for the private equity group. Transaction features appear to be highly correlated, with preferred stock transactions being associated with the greater use of a variety of contractual protections, while the use of other securities is associated with the private equity group having a larger equity stake.

- Board structures are little different from the U.S. Transactions in common law nations have greater founder and manager board representation, suggesting that board composition may substitute for contractual provisions.

- While U.K.- and U.S.-based private equity groups are more likely to write contracts that resemble provisions in their home countries, they are not able to fully replicate U.S.-style contracts and adjust many provisions to the local environment. 
- These contractual differences appear to have real consequences: larger transactions with higher valuations are seen in common law countries.

- These differences in transactions across nations are not simply consequences of the actual legal curbs in these nations. The patterns continue to hold when we eliminate nations where the financing choice is "hard wired" by the law.

We believe that this study makes two contributions. First, because of the relatively simple yet well-documented nature of these contracts, we can readily test theories of corporate finance across different institutional environments. The results that emerge from this analysis simultaneously are consistent with and extend the findings of the law and finance literature, which has largely focused on public firms. Second, the topic of private equity investment in developing countries is an important topic in its own right: at least $\$ 15$ billion of international development aid alone has been channeled through these funds (Brenner [1999]).

This analysis, it should be noted, leaves questions unanswered about private equity contracts in developing countries. Key issues include why we do not see the use transaction structures familiar from the United States setting in developing countries, and how detrimental these differences are. One possible explanation is that investors demand controlling blocks because courts and laws do not adequately protect minority shareholders. Given the necessity to rely on controlling stakes, investors might (optimally) choose common stock over preferred as a second best outcome, if preferred stock gives too much cash flow and control rights to the investor. 
There are also other important questions about private equity in developing countries that we do not address in this paper. Foremost among these are the apparently disappointing returns that these investments have yielded over the past decade and the declining share of all private equity investments that they represent. From where have the difficulties encountered by private equity investments in developing countries sprung? Are these a function of the general macroeconomic troubles that led to public equity investors in many developing countries to experience low returns during much of the 1990s? Or do the difficulties stem from the differences in transaction structures from the U.S. template that we have highlighted above? ${ }^{13}$

A second important topic for further research relates to the role of government programs. National governments and multinational development organizations have made substantial investments to stimulate the growth of private equity. These initiatives have taken many forms, from direct investments in entrepreneurial firms to the provision of subsidies to private equity groups. How effective have these efforts been? Do any approaches appear to have been particularly successful?

\footnotetext{
${ }^{13} \mathrm{~A}$ related issue is the similarities and differences between the structure of private and public equity investments in developing nations. The work of Bergman and Nicolaievsky [2003] highlights the differences between these contracts in the Mexican setting. A cross-national analysis of these differences would be a rewarding analysis.
} 


\section{References}

Acemoglu, Daron, Simon Johnson, and James A. Robinson, 2001, "The Colonial Origins of Comparative Development: An Empirical Investigation," American Economic Review, 91, 1369-1401.

Bartlett, Joseph W., 1995, Equity Finance: Venture Capital, Buyouts, Restructurings, and Reorganizations, $2^{\text {nd }}$ edition, New York, John Wiley.

Bergman, Nittai, and Daniel Nicolaievsky, 2003, "Investor Protection and the Coasian View," Unpublished working paper, Harvard University.

Brenner, James C., 1999, "Direct Equity Investment Funds: Public-Private Partnership Experience," Unpublished working paper, Harvard University.

Cumming, Douglas J., and Jeffrey G. MacIntosh, 2002, "A Law and Finance Analysis of Venture Capital Exits in Emerging Markets," Unpublished working paper, University of Alberta.

Demirgüc-Kunt, Asli, and Ross Levine, 2001, Financial Structure and Economic Growth: A Cross-Country Comparison of Banks, Markets, and Development, Cambridge, MIT Press.

Djankov, Simeon, Rafael La Porta, Florencio Lopez-de-Silanes, and Andrei Shleifer, 2002a, "Courts: The Lex Mundi Project," Working Paper no. 8890, National Bureau of Economic Research.

Djankov, Simeon, Rafael La Porta, Florencio Lopez-de-Silanes, and Andrei Shleifer, 2002b, “The Regulation of Entry," Quarterly Journal of Economics, 117, 1-37.

European Venture Capital Association, 2002, EVCA Yearbook, Zaventum, Belgium, EVCA and KPMG.

Gennaioli, Niccolai, 2003, "Contracting in the Shadow of the Law," Unpublished working paper, Harvard University.

Gompers, Paul A., 1995, "Optimal Investing, Monitoring, and the Staging of Venture Capital," Journal of Finance, 50, 1461-1490.

Gompers, Paul A., 1998, "An Examination of Convertible Securities in Venture Capital Investments," Unpublished working paper, Harvard University.

Gompers, Paul, and Josh Lerner, 2000, "Money Chasing Deals? The Impact of Fund Inflows on Private Equity Valuations," Journal of Financial Economics, 55, 281-325. 
Jeng, Leslie A., and Philippe C. Wells, 2000, "The Determinants of Venture Capital Funding: Evidence across Countries," Journal of Corporate Finance: Contracting, Governance \& Organization, 6, 241-289.

Johnson, Simon, John McMillan, and Christopher Woodruff, 2002, "Courts and Relational Contracts," Journal of Law, Economics and Organization, 18, 221-277.

Kaplan, Steven N., Frederic Martel, and Per Strömberg, 2003, "How Do Legal Differences and Learning Affect Financial Contracts?," Working Paper no. 10097, National Bureau of Economic Research.

Kaplan, Steven N., and Per Strömberg, 2003, "Financial Contracting Meets the Real World: An Empirical Analysis of Venture Capital Contracts," Review of Economic Studies, 70, 281-316.

La Porta, Rafael, Florencio Lopez-de-Silanes, Andrei Shleifer, and Robert Vishny, 1997, "Legal Determinants of External Finance," Journal of Finance, 52, 1131-1150.

La Porta, Rafael, Florencio Lopez-de-Silanes, Andrei Shleifer, and Robert Vishny, 1998, "Law and Finance," Journal of Political Economy, 106, 1133-1155.

La Porta, Rafael, Florencio Lopez-de-Silanes, Andrei Shleifer, and Robert Vishny, 1999, "The Quality of Government," Journal of Law, Economics, and Organization, 15, 222279.

La Porta, Rafael, Florencio Lopez-de-Silanes, Andrei Shleifer, and Robert Vishny, 2002, "Investor Protection and Corporate Valuation," Journal of Finance, 57, 1147-1170. 
Table 1-Construction of sample. This table summarizes the key features associated with the construction of the sample of 210 private equity transactions.

\begin{tabular}{|c|c|c|c|c|c|c|c|c|c|}
\hline \multicolumn{2}{|c|}{$\begin{array}{c}\text { Private Equity } \\
\text { Group }\end{array}$} & \multicolumn{2}{|c|}{ Year of Deal } & \multicolumn{2}{|c|}{ Industry of Firm } & \multicolumn{2}{|c|}{ Deal Type } & \multicolumn{2}{|c|}{ Country of Firm } \\
\hline Group 1 & 8 & 1987 & 2 & Distribution/Retail & 14 & Buyout & 28 & Argentina & 18 \\
\hline Group 2 & 6 & 1988 & 2 & Finance & 16 & Corp. Acquisition & 10 & Bolivia & 2 \\
\hline Group 3 & 6 & 1992 & 3 & Food & 29 & Distress & 4 & Brazil & 18 \\
\hline Group 4 & 5 & 1993 & 4 & Health Care & 9 & Expansion & 97 & Bulgaria & 8 \\
\hline Group 5 & 3 & 1994 & 2 & Information Tech & 24 & IPO & 12 & Chile & 7 \\
\hline Group 6 & 3 & 1995 & 5 & Internet & 9 & Privatization & 10 & China & 13 \\
\hline Group 7 & 10 & 1996 & 10 & Manufacturing & 32 & Venture Capital & 49 & Estonia & 8 \\
\hline Group 8 & 8 & 1997 & 17 & Media & 8 & & & Ghana & 3 \\
\hline Group 9 & 6 & 1998 & 35 & Natural Resources & 11 & & & Hong Kong & 13 \\
\hline Group 10 & 6 & 1999 & 31 & Real Estate & 4 & & & India & 28 \\
\hline Group 11 & 11 & 2000 & 34 & Services & 17 & & & Korea & 10 \\
\hline Group 12 & 3 & 2001 & 40 & Software & 10 & & & Indonesia & 2 \\
\hline Group 13 & 2 & 2002 & 22 & Telecom & 14 & & & Latvia & 4 \\
\hline Group 14 & 4 & 2003 & 3 & Other & 13 & & & Malaysia & 2 \\
\hline Group 15 & 10 & & & & & & & Mexico & 14 \\
\hline Group 16 & 8 & & & & & & & Peru & 2 \\
\hline Group 17 & 6 & & & & & & & Poland & 13 \\
\hline Group 18 & 5 & & & & & & & Romania & 18 \\
\hline Group 19 & 10 & & & & & & & Singapore & 6 \\
\hline Group 20 & 13 & & & & & & & South Africa & 2 \\
\hline Group 21 & 14 & & & & & & & Taiwan & 4 \\
\hline Group 22 & 8 & & & & & & & Tanzania & 2 \\
\hline Group 23 & 5 & & & & & & & Thailand & 3 \\
\hline Group 24 & 7 & & & & & & & Uruguay & 2 \\
\hline Group 25 & 21 & & & & & & & Yugoslavia & 6 \\
\hline Group 26 & 13 & & & & & & & Other & 5 \\
\hline Group 27 & 7 & & & & & & & & \\
\hline Group 28 & 2 & & & & & & & & \\
\hline
\end{tabular}


Table 2-Characteristics of developing country private equity transactions. The sample consists of 210 investments in developing countries by private equity groups (PEGs). The first panel describes the features of the transactions; the second panel, the features of the nation and the private equity group involved in the transaction. We do not record the medians and standard deviations of the dummy variables.

\begin{tabular}{|c|c|c|c|c|c|}
\hline \multicolumn{6}{|c|}{ Panel A: Setting of Transactions } \\
\hline & Mean & Median & $\underline{\text { Standard Dev }}$ & $\underline{\text { Minimum }}$ & $\underline{\text { Maximum }}$ \\
\hline Per capita gross national product & 2142 & 1743 & 2561 & 181 & 12368 \\
\hline Logarithm of rule of law index & 0.22 & 0.28 & 0.59 & -1.25 & 1.85 \\
\hline English legal family nation & 0.27 & & & 0 & 1 \\
\hline French legal family nation & 0.30 & & & 0 & 1 \\
\hline Socialist legal family country & 0.42 & & & 0 & 1 \\
\hline U.K. or U.S.-based private equity group & 0.56 & & & 0 & 1 \\
\hline \multicolumn{6}{|c|}{ Panel B: Nature of Transactions } \\
\hline & Mean & Median & $\underline{\text { Standard Dev }}$ & Minimum & Maximum \\
\hline Size of financing (1997 \$MMs) & 4.31 & 3.29 & 5.12 & 0.17 & 18.53 \\
\hline Implied valuation (1997 \$MMs) & 5.12 & 4.18 & 4.92 & 0.45 & $61.38^{\mathrm{a}}$ \\
\hline Straight debt & 0.11 & & & 0 & 1 \\
\hline Convertible debt & 0.13 & & & 0 & 1 \\
\hline Common stock & 0.55 & & & 0 & 1 \\
\hline Straight preferred stock & 0.09 & & & 0 & 1 \\
\hline Participating preferred stock & 0.05 & & & 0 & 1 \\
\hline Convertible preferred stock & 0.21 & & & 0 & 1 \\
\hline Warrants & 0.06 & & & 0 & 1 \\
\hline Contingent equity & 0.34 & & & 0 & 1 \\
\hline PEG's maximum equity stake & 0.47 & 0.40 & 0.37 & 0 & 1 \\
\hline PEG's minimum equity stake & 0.33 & 0.38 & 0.38 & 0 & 1 \\
\hline Difference in PEG ownership & 0.15 & 0.01 & 0.26 & 0 & 1 \\
\hline PEG has control when maximum stake & 0.37 & & & 0 & 1 \\
\hline PEG has control when minimum stake & 0.29 & & & 0 & 1 \\
\hline Anti-dilution provisions & 0.27 & & & 0 & 1 \\
\hline Automatic conversion provisions & 0.26 & & & 0 & 1 \\
\hline PEG has redemption rights & 0.31 & & & 0 & 1 \\
\hline PEG protected against down rounds & 0.10 & & & 0 & 1 \\
\hline Vesting of founders & 0.05 & & & 0 & 1 \\
\hline Restrictions on founder stock sales & 0.49 & & & 0 & 1 \\
\hline Maximum board size & 6.50 & 6 & 2.03 & 3 & 12 \\
\hline Minimum board size & 5.40 & 5 & 1.95 & 3 & 11 \\
\hline Maximum PEG board seats & 2.66 & 2 & 1.89 & 0 & 9 \\
\hline Minimum PEG board seats & 1.35 & 1 & 1.24 & 0 & 6 \\
\hline Maximum founder/manager board seats & 3.22 & 3 & 1.87 & 0 & 7 \\
\hline Minimum founder/manager board seats & 2.47 & 2 & 1.72 & 0 & 6 \\
\hline Supermajority sum & 18.47 & 15 & 12.98 & 0 & 57 \\
\hline
\end{tabular}

${ }^{a}$ The size of the financing is greater than the valuation in the largest transaction (a leveraged buyout which entailed the purchase of all of the firm's equity) because part of the financing proceeds were used to cover fees to investment bankers, lawyers, and others. 
Table 3-Description of non-standard characteristics of developing country private equity transactions. The sample consists of 210 investments in developing countries by private equity groups (PEGs).

\section{Panel A: Exit Provisions}

Contract specifies trade sale to strategic buyer as exit goal, not IPO

Frequency

If exit is not reached within stated time, firm has to pay annual dividends $>50 \%$ of profits

PEG has a put that can be triggered at any time if there are disagreements with management

PEG is investing along side a strategic buyer who might ultimately buy the firm

If exit is not reached within stated time, PEG can put back money to parent company of firm

Contract pre-specifies an "arbitrator", for example an investment bank, in case of discrepancies

between shareholders to avoid delays in the courts

If exit is not reached in stated time, PEG can put back shares at a price agreed upon by at least

three "reputable" investment banks

\section{Panel B: Financing Provisions}

Debt converts to equity if firm defaults

PEG issues debt that is backed by guarantees of the parent company of a firm

"Forgivable" debt: if firms reaches certain earnings targets, loan is converted into $0 \%$ equity

Majority shareholder of company issues the bond, not company, to avoid political constraints

Government debt becomes subordinate to equity if the firm defaults

Panel C: Anti-Dilution Provisions

No anti-dilution rights per se, but existing investors have to approve issuance of new shares PEG equity stake remains unchanged independent of valuation in next round

\section{Panel D: Other Provisions}

Business dealings with firms owned by family members of the founders/managers have to be approved by PEG

Founder family members agree not to be involved in competing business unless approved by the PEG 
Table 4-Regression analyses of security type in developing country private equity transactions. The sample consists of 210 investments in developing countries by private equity groups (PEGs). The dependent variables are dummies denoting whether common stock was employed in the transaction, straight debt was employed in the transaction, preferred stock was employed in the transaction, the equity stake is contingent on the performance of the firm, and the presence of caps and/or floors on the payouts to the PEGs. Independent variables include the logarithms of an index of the rule of law and per capita gross national product, and dummy variables denoting nations with British or French legal origins and funds based in the U.K. or U.S. All regressions employ ordinary least squares specifications. Standard errors are in brackets.

\begin{tabular}{|c|c|c|c|c|}
\hline \multirow{3}{*}{ Rule of law index } & \multicolumn{3}{|c|}{ Panel A: Use of Straight Debt } & \multirow{3}{*}{$\begin{array}{r}-0.16 \\
{[0.09]}\end{array}$} \\
\hline & -0.03 & -0.03 & -0.03 & \\
\hline & {$[0.06]$} & [0.09] & {$[0.08]$} & \\
\hline \multirow[t]{2}{*}{ British legal origins } & -0.14 & -0.14 & -0.16 & -0.05 \\
\hline & $* * *[0.06]$ & $* * *[0.06]$ & $* * *[0.07]$ & {$[0.18]$} \\
\hline \multirow[t]{2}{*}{ French legal origins } & & 0.12 & 0.11 & 0.26 \\
\hline & & $* * *[0.06]$ & $* *[0.06]$ & $*[0.15]$ \\
\hline \multirow[t]{2}{*}{ GNP per capita } & -0.03 & -0.04 & -0.04 & -0.07 \\
\hline & [0.07] & [0.07] & {$[0.08]$} & {$[0.08]$} \\
\hline \multirow[t]{2}{*}{ U.K. or U.S. based PEG } & & & -0.12 & \\
\hline & & & $* * *[0.05]$ & \\
\hline \multirow[t]{2}{*}{ Judicial Efficiency } & & & & -0.04 \\
\hline & & & & {$[0.18]$} \\
\hline Industry dummies & Y & $\mathrm{Y}$ & $\mathrm{Y}$ & $\mathrm{Y}$ \\
\hline Deal type dummies & Y & Y & $\mathrm{Y}$ & Y \\
\hline Year dummies & $\mathrm{Y}$ & $\mathrm{Y}$ & $\mathrm{Y}$ & $\mathrm{Y}$ \\
\hline Number of observations & 210 & 210 & 210 & 182 \\
\hline \multirow{2}{*}{ Adjusted $\mathrm{R}^{2}$} & 0.18 & 0.19 & 0.21 & 0.23 \\
\hline & Panel B: Us & Common St & & \\
\hline \multirow[t]{2}{*}{ Rule of law index } & -0.05 & -0.02 & -0.02 & -0.02 \\
\hline & [0.11] & [0.09] & [0.10] & [0.11] \\
\hline \multirow[t]{2}{*}{ British legal origins } & -0.16 & -0.16 & -0.15 & -0.38 \\
\hline & $* *[0.09]$ & $* *[0.09]$ & $* *[0.08]$ & $* *[0.26]$ \\
\hline \multirow{2}{*}{ French legal origins } & & -0.14 & -0.13 & -0.31 \\
\hline & & $*[0.10]$ & $*[0.10]$ & {$[0.28]$} \\
\hline \multirow[t]{2}{*}{ GNP per capita } & -0.15 & -0.14 & -0.13 & -0.11 \\
\hline & $* *[0.08]$ & $*[0.11]$ & $*[0.11]$ & {$[0.11]$} \\
\hline \multirow[t]{2}{*}{ U.K. or U.S. based PEG } & & & -0.15 & \\
\hline & & & $* * *[0.07]$ & \\
\hline Judicial Efficiency & & & & $\begin{array}{c}-0.08 \\
{[0.09]}\end{array}$ \\
\hline Industry dummies & Y & $\mathrm{Y}$ & $\mathrm{Y}$ & $\mathrm{Y}$ \\
\hline Deal type dummies & Y & Y & $\mathrm{Y}$ & Y \\
\hline Year dummies & Y & Y & Y & $\mathrm{Y}$ \\
\hline Number of observations & 210 & 210 & 210 & 182 \\
\hline Adjusted $\mathrm{R}^{2}$ & 0.19 & 0.21 & 0.22 & 0.24 \\
\hline
\end{tabular}




\begin{tabular}{lcrrr}
\hline & Panel C: Use of Preferred Stock & & \\
Rule of law index & 0.08 & 0.13 & 0.12 & 0.07 \\
& {$[0.07]$} & $*[0.08]$ & {$[012]$} & {$[0.13]$} \\
British legal origins & 0.23 & 0.24 & 0.23 & 0.67 \\
& $* *[0.13]$ & $* *[0.13]$ & $* *[0.11]$ & $* * *[0.28]$ \\
French legal origins & & 0.11 & 0.09 & 0.60 \\
& & {$[0.09]$} & {$[0.10]$} & $* *[0.30]$ \\
GNP per capita & 0.07 & 0.07 & 0.10 & 0.11 \\
& {$[0.10]$} & {$[0.10]$} & {$[0.09]$} & {$[0.12]$} \\
U.K. or U.S. based PEG & & & $* * 15$ & \\
& & & & \\
Judicial Efficiency & & & & $* 0.08]$ \\
& $\mathrm{Y}$ & $\mathrm{Y}$ & $\mathrm{Y}$ & 0.49 \\
Industry dummies & $\mathrm{Y}$ & $\mathrm{Y}$ & $\mathrm{Y}$ & $\mathrm{Y}$ \\
Deal type dummies & $\mathrm{Y}$ & $\mathrm{Y}$ & $\mathrm{Y}$ & $\mathrm{Y}$ \\
Year dummies & 210 & 210 & 210 & 182 \\
Number of observations & 0.16 & 0.18 & 0.21 & 0.24 \\
Adjusted R & & & & \\
\hline \hline
\end{tabular}

$*=$ Significant at the $10 \%$ level; $* *=$ significant at the $5 \%$ level; $* * *=$ significant at the $1 \%$ level. 
Table 5-Regression analyses of equity ownership in developing country private equity transactions. The sample consists of 210 investments in developing countries by private equity groups (PEGs). The dependent variables are dummies denoting whether the PEG has control of the firm's equity when it has its maximum and minimum contractually specified share of the equity, and the difference in the equity ownership stake in these two scenarios. Independent variables include the logarithms of an index of the rule of law and per capita gross national product, and dummy variables denoting nations with British or French legal origins and funds based in the U.K. or U.S. All regressions employ ordinary least squares specifications. Standard errors are in brackets.

\begin{tabular}{|c|c|c|c|c|}
\hline \multicolumn{5}{|c|}{ Panel A: Does PEG Have Control When Minimum Stake? } \\
\hline \multirow[t]{2}{*}{ Rule of law index } & -0.16 & -0.12 & -0.13 & -0.06 \\
\hline & $* * *[0.07]$ & $*[0.08]$ & $*[0.08]$ & [0.12] \\
\hline \multirow[t]{2}{*}{ British legal origins } & -0.03 & -0.02 & -0.01 & -0.41 \\
\hline & {$[0.08]$} & [0.08] & [0.08] & $*[0.29]$ \\
\hline \multirow[t]{2}{*}{ French legal origins } & & 0.19 & 0.11 & 0.58 \\
\hline & & $* * *[0.05]$ & $* *[0.06]$ & $* * *[0.21]$ \\
\hline \multirow{2}{*}{ GNP per capita } & 0.12 & 0.09 & 0.11 & 0.05 \\
\hline & $* * *[0.05]$ & $* *[0.05]$ & $* *[0.06]$ & [0.07] \\
\hline \multirow[t]{2}{*}{ U.K. or U.S. based PEG } & & & -0.11 & \\
\hline & & & $* * *[0.05]$ & \\
\hline Judicial Efficiency & & & & $\begin{array}{r}-0.26 \\
*[0.17]\end{array}$ \\
\hline Industry dummies & $\mathrm{Y}$ & $\mathrm{Y}$ & Y & $\mathrm{Y}$ \\
\hline Deal type dummies & Y & Y & Y & $\mathrm{Y}$ \\
\hline Year dummies & $\mathrm{Y}$ & Y & $\mathrm{Y}$ & $\mathrm{Y}$ \\
\hline Number of observations & 194 & 194 & 194 & 171 \\
\hline Adjusted $\mathrm{R}^{2}$ & 0.18 & 0.19 & 0.21 & 0.23 \\
\hline \multicolumn{5}{|c|}{ Panel B: Does PEG Have Control When Maximum Stake? } \\
\hline \multirow[t]{2}{*}{ Rule of law index } & -0.25 & -0.26 & -0.29 & -0.14 \\
\hline & $* * *[0.08]$ & $* * *[0.09]$ & $* * *[0.09]$ & $*[0.11]$ \\
\hline \multirow[t]{2}{*}{ British legal origins } & 0.15 & 0.13 & 0.15 & 0.93 \\
\hline & $*[0.10]$ & $*[0.09]$ & $* *[0.08]$ & $* * *[0.33]$ \\
\hline \multirow[t]{2}{*}{ French legal origins } & & 0.01 & 0.04 & 0.20 \\
\hline & & [0.06] & {$[0.06]$} & $* *[0.09]$ \\
\hline \multirow[t]{2}{*}{ GNP per capita } & 0.19 & 0.19 & 0.21 & 0.23 \\
\hline & $* * *[0.06]$ & $* * *[0.07]$ & $* * *[0.08]$ & $* * *[0.08]$ \\
\hline \multirow[t]{2}{*}{ U.K. or U.S. based PEG } & & & 0.09 & \\
\hline & & & $*[0.06]$ & \\
\hline Judicial Efficiency & & & & -0.34 \\
\hline & Y & $Y$ & $Y$ & $\begin{aligned} {[0.20] } \\
Y\end{aligned}$ \\
\hline Deal type dummies & $\mathrm{Y}$ & $\mathrm{Y}$ & $\mathrm{Y}$ & $\mathrm{Y}$ \\
\hline Year dummies & $\mathrm{Y}$ & Y & $\mathrm{Y}$ & $\mathrm{Y}$ \\
\hline Number of observations & 194 & 194 & 194 & 171 \\
\hline Adjusted $\mathrm{R}^{2}$ & 0.17 & 0.20 & 0.21 & 0.22 \\
\hline \multicolumn{5}{|c|}{ Panel C: Difference Between Maximum and Minimum PEG Stake } \\
\hline \multirow{2}{*}{ Rule of law index } & -0.08 & -0.09 & -0.06 & -0.14 \\
\hline & $*[0.05]$ & $*[0.06]$ & {$[0.06]$} & $* *[0.08]$ \\
\hline \multirow[t]{2}{*}{ British legal origins } & 0.14 & 0.14 & 0.13 & 0.39 \\
\hline & $* * *[0.06]$ & $* * *[0.06]$ & $* * *[0.06]$ & $*[0.27]$ \\
\hline \multirow[t]{2}{*}{ French legal origins } & & -0.04 & -0.03 & -0.18 \\
\hline & & [0.04] & {$[0.04]$} & [0.24] \\
\hline \multirow[t]{2}{*}{ GNP per capita } & 0.07 & 0.06 & 0.05 & 0.15 \\
\hline & $* *[0.04]$ & $* *[0.04]$ & $*[0.04]$ & $* * *[0.06]$ \\
\hline \multirow[t]{2}{*}{ U.K. or U.S. based PEG } & & & 0.03 & \\
\hline & & & {$[0.03]$} & \\
\hline
\end{tabular}




\begin{tabular}{lrrrr}
\hline \hline Judicial Efficiency & & & -0.07 \\
& & & & {$[0.13]$} \\
Industry dummies & $\mathrm{Y}$ & $\mathrm{Y}$ & $\mathrm{Y}$ & $\mathrm{Y}$ \\
Deal type dummies & $\mathrm{Y}$ & $\mathrm{Y}$ & $\mathrm{Y}$ & $\mathrm{Y}$ \\
Year dummies & $\mathrm{Y}$ & $\mathrm{Y}$ & $\mathrm{Y}$ & $\mathrm{Y}$ \\
Number of observations & 194 & 194 & 194 & 171 \\
Adjusted R & 0.16 & 0.17 & 0.19 & 0.21 \\
\hline \hline
\end{tabular}

$*=$ Significant at the $10 \%$ level; $* *=$ significant at the $5 \%$ level; $* * *=$ significant at the $1 \%$ level. 
Table 6-Regression analyses of control rights in developing country private equity transactions. The sample consists of 210 investments in developing countries by private equity groups (PEGs). The dependent variables are dummies denoting whether the PEG group has anti-dilution protection, redemption rights, and automatic conversion requirements. Independent variables include the logarithms of an index of the rule of law and per capita gross national product, and dummy variables denoting nations with British or French legal origins and funds based in the U.K. or U.S. All regressions employ ordinary least squares specifications. Standard errors are in brackets.

\begin{tabular}{|c|c|c|c|c|}
\hline \multicolumn{5}{|c|}{ Panel A: Anti-Dilution Protection } \\
\hline \multirow[t]{2}{*}{ Rule of law index } & 0.08 & 0.05 & 0.02 & 0.02 \\
\hline & {$[0.11]$} & [0.12] & [012] & [0.14] \\
\hline \multirow[t]{2}{*}{ British legal origins } & 0.33 & 0.34 & 0.33 & 0.34 \\
\hline & $* * *[0.13]$ & $* * *[0.13]$ & $* * *[0.13]$ & $* * *[0.13]$ \\
\hline \multirow[t]{2}{*}{ French legal origins } & & 0.08 & 0.12 & 0.14 \\
\hline & & {$[0.10]$} & {$[0.10]$} & $*[0.10]$ \\
\hline \multirow[t]{2}{*}{ GNP per capita } & 0.17 & 0.16 & 0.14 & 0.10 \\
\hline & $* *[0.09]$ & $* *[0.09]$ & $*[0.10]$ & [0.14] \\
\hline \multirow[t]{2}{*}{ U.K. or U.S. based PEG } & & & 0.14 & \\
\hline & & & $* *[0.08]$ & \\
\hline \multirow[t]{2}{*}{ Judicial Efficiency } & & & & 0.28 \\
\hline & & & & [0.31] \\
\hline Industry dummies & Y & $\mathrm{Y}$ & $\mathrm{Y}$ & $\mathrm{Y}$ \\
\hline Deal type dummies & Y & Y & $\mathrm{Y}$ & $\mathrm{Y}$ \\
\hline Year dummies & $\mathrm{Y}$ & Y & $\mathrm{Y}$ & Y \\
\hline Number of observations & 210 & 210 & 210 & 184 \\
\hline Adjusted $\mathrm{R}^{2}$ & 0.17 & 0.19 & 0.22 & 0.25 \\
\hline \multicolumn{5}{|c|}{ Panel B: Redemption Rights } \\
\hline \multirow[t]{2}{*}{ Rule of law index } & 0.04 & 0.04 & 0.03 & 0.15 \\
\hline & {$[0.12]$} & {$[0.12]$} & {$[0.12]$} & [0.13] \\
\hline \multirow[t]{2}{*}{ British legal origins } & 0.04 & 0.04 & 0.04 & 0.39 \\
\hline & [0.13] & [0.13] & {$[0.14]$} & $*[0.24]$ \\
\hline \multirow{2}{*}{ French legal origins } & & -0.01 & -0.01 & -0.34 \\
\hline & & {$[0.10]$} & {$[0.10]$} & [0.27] \\
\hline \multirow[t]{2}{*}{ GNP per capita } & 0.10 & 0.10 & 0.17 & 0.03 \\
\hline & {$[0.09]$} & {$[0.10]$} & {$[0.10]$} & [0.11] \\
\hline \multirow[t]{2}{*}{ U.K. or U.S. based PEG } & & & 0.20 & \\
\hline & & & $* * *[0.08]$ & \\
\hline \multirow[t]{2}{*}{ Judicial efficiency } & & & & 0.23 \\
\hline & & & & [0.26] \\
\hline Industry dummies & $\mathrm{Y}$ & $\mathrm{Y}$ & Y & $\mathrm{Y}$ \\
\hline Deal type dummies & $\mathrm{Y}$ & $\mathrm{Y}$ & $\mathrm{Y}$ & Y \\
\hline Year dummies & $\mathrm{Y}$ & $\mathrm{Y}$ & $\mathrm{Y}$ & $\mathrm{Y}$ \\
\hline Number of observations & 210 & 210 & 210 & 184 \\
\hline Adjusted $\mathrm{R}^{2}$ & 0.09 & 0.12 & 0.13 & 0.14 \\
\hline \multicolumn{5}{|c|}{ Panel C: Automatic Conversion } \\
\hline \multirow[t]{2}{*}{ Rule of law index } & -0.17 & -0.15 & -0.09 & -0.27 \\
\hline & $*[0.11]$ & $*[0.11]$ & [0.11] & $*[0.17]$ \\
\hline \multirow[t]{2}{*}{ British legal origins } & 0.22 & 0.22 & 0.20 & 0.45 \\
\hline & $* *[0.12]$ & $* *[0.12]$ & $*[0.12]$ & $*[0.29]$ \\
\hline \multirow[t]{2}{*}{ French legal origins } & & 0.04 & 0.03 & 0.11 \\
\hline & & {$[0.10]$} & {$[0.10]$} & [0.34] \\
\hline \multirow[t]{2}{*}{ GNP per capita } & 0.18 & 0.17 & 0.17 & 0.27 \\
\hline & $* * *[0.09]$ & $* *[0.09]$ & $* *[0.09]$ & $* * *[0.13]$ \\
\hline \multirow[t]{2}{*}{ U.K. or U.S. based PEG } & & & 0.22 & \\
\hline & & & $* * *[0.08]$ & \\
\hline Judicial Efficiency & & & & 0.25 \\
\hline
\end{tabular}




\begin{tabular}{lrrrr}
\hline \hline & & & {$[0.32]$} \\
Industry dummies & $\mathrm{Y}$ & $\mathrm{Y}$ & $\mathrm{Y}$ & $\mathrm{Y}$ \\
Deal type dummies & $\mathrm{Y}$ & $\mathrm{Y}$ & $\mathrm{Y}$ & $\mathrm{Y}$ \\
Year dummies & $\mathrm{Y}$ & $\mathrm{Y}$ & $\mathrm{Y}$ & $\mathrm{Y}$ \\
Number of observations & 210 & 210 & 210 & 184 \\
Adjusted R $^{2}$ & 0.07 & 0.09 & 0.10 & 0.12 \\
\hline
\end{tabular}

$*=$ Significant at the $10 \%$ level; $* *=$ significant at the $5 \%$ level; $* * *=$ significant at the $1 \%$ level. 
Table 7-Regression analyses of restrictions on founders' and managers' equity stakes in developing country private equity transactions. The sample consists of 81 investments in developing countries by private equity groups (PEGs). The dependent variables are dummies denoting if the shares of the firms' founders and managers must vest and if there are restrictions on securities sales by founders and managers. Independent variables include the logarithms of an index of property rights and per capita gross national product, and dummy variables denoting nations with British or French legal origins and funds based in a common law nation. All regressions employ ordinary least squares specifications. Standard errors are in brackets.

\begin{tabular}{|c|c|c|c|c|}
\hline \multicolumn{5}{|c|}{ Panel A: Vesting of Founder and Manager Stock } \\
\hline \multirow[t]{2}{*}{ Rule of law index } & 0.02 & 0.07 & 0.03 & 0.01 \\
\hline & [0.13] & {$[0.16]$} & [0.16] & [0.15] \\
\hline \multirow[t]{2}{*}{ British legal origins } & 0.04 & -0.01 & 0.06 & 0.08 \\
\hline & [0.07] & [0.12] & [0.10] & [0.11] \\
\hline \multirow{2}{*}{ French legal origins } & & -0.06 & -0.05 & -0.06 \\
\hline & & [0.07] & [0.07] & [0.07] \\
\hline \multirow[t]{2}{*}{ GNP per capita } & 0.01 & -0.04 & -0.03 & -0.01 \\
\hline & {$[0.04]$} & {$[0.05]$} & {$[0.05]$} & [0.04] \\
\hline \multirow[t]{2}{*}{ U.K. or U.S. based PEG } & & & 0.07 & \\
\hline & & & {$[0.06]$} & \\
\hline Judicial Efficiency & & & & $\begin{array}{r}0.04 \\
{[0.03]}\end{array}$ \\
\hline Industry dummies & Y & $\mathrm{Y}$ & Y & $\mathrm{Y}$ \\
\hline Deal type dummies & Y & Y & Y & Y \\
\hline Year dummies & Y & Y & $\mathrm{Y}$ & $\mathrm{Y}$ \\
\hline Number of observations & 76 & 76 & 76 & 76 \\
\hline Adjusted $\mathrm{R}^{2}$ & 0.02 & 0.02 & 0.04 & 0.04 \\
\hline \multicolumn{5}{|c|}{ Panel B: Restrictions on Sales of Founder and Manager Stock } \\
\hline \multirow[t]{2}{*}{ Rule of law index } & -0.62 & -0.63 & -0.63 & -0.60 \\
\hline & $*[0.32]$ & $*[0.35]$ & $*[0.34]$ & [0.44] \\
\hline \multirow[t]{2}{*}{ British legal origins } & 0.06 & 0.06 & 0.07 & 0.07 \\
\hline & [0.22] & {$[0.26]$} & {$[0.25]$} & [0.25] \\
\hline \multirow[t]{2}{*}{ French legal origins } & & 0.004 & 0.004 & 0.004 \\
\hline & & {$[0.16]$} & {$[0.18]$} & [0.18] \\
\hline \multirow[t]{2}{*}{ GNP per capita } & -0.01 & -0.01 & -0.01 & -0.01 \\
\hline & {$[0.10]$} & {$[0.10]$} & {$[0.11]$} & [0.11] \\
\hline \multirow[t]{2}{*}{ Common law based PEG } & & & 0.02 & \\
\hline & & & {$[0.14]$} & \\
\hline \multirow[t]{2}{*}{ Judicial Efficiency } & & & & 0.09 \\
\hline & & & & $\begin{aligned}0.7] \\
\mathrm{Y}\end{aligned}$ \\
\hline Industry dummies & $\mathrm{Y}$ & $\mathrm{Y}$ & $\mathrm{Y}$ & $\mathrm{Y}$ \\
\hline Deal type dummies & $\mathrm{Y}$ & $\mathrm{Y}$ & $\mathrm{Y}$ & $\mathrm{Y}$ \\
\hline Year dummies & $\mathrm{Y}$ & Y & $\mathrm{Y}$ & $\mathrm{Y}$ \\
\hline Number of observations & 76 & 76 & 76 & 76 \\
\hline Adjusted $\mathrm{R}^{2}$ & 0.06 & 0.07 & 0.08 & 0.07 \\
\hline
\end{tabular}

$*=$ Significant at the $10 \%$ level; $* *=$ significant at the $5 \%$ level; $* * *=$ significant at the $1 \%$ level. 
Table 8-Regression analyses of board seats in developing country private equity transactions. The sample consists of 210 investments in developing countries by private equity groups (PEGs). The dependent variables are the logarithms of the maximum number of seats on the board, as well as the maximum assigned the founders and managers and the PEG. Independent variables include the logarithms of an index of the rule of law and per capita gross national product, and dummy variables denoting nations with British or French legal origins and funds based in the U.K. or U.S. All regressions employ ordinary least squares specifications. Standard errors are in brackets.

\begin{tabular}{|c|c|c|c|c|}
\hline \multicolumn{5}{|c|}{ Panel A: Total Maximum Board Seats } \\
\hline \multirow[t]{2}{*}{ Rule of law index } & -0.09 & -0.09 & -0.16 & -0.19 \\
\hline & [0.11] & {$[0.12]$} & $*[0.12]$ & $*[0.15]$ \\
\hline \multirow[t]{2}{*}{ British legal origins } & 0.31 & 0.33 & 0.36 & 0.08 \\
\hline & $* * *[0.11]$ & $* * *[0.11]$ & $* * *[0.12]$ & [0.19] \\
\hline \multirow[t]{2}{*}{ French legal origins } & & -0.06 & -0.14 & -0.12 \\
\hline & & [0.09] & $*[0.09]$ & [0.19] \\
\hline \multirow[t]{2}{*}{ GNP per capita } & 0.09 & 0.09 & 0.14 & 0.16 \\
\hline & [0.09] & [0.09] & $*[0.10]$ & [0.12] \\
\hline \multirow[t]{2}{*}{ U.K. or U.S. based PEG } & & & 0.15 & \\
\hline & & & $* * *[0.07]$ & \\
\hline Judicial Efficiency & & & & -0.28 \\
\hline Industry dummies & Y & $\mathrm{Y}$ & Y & $\begin{array}{r}{[0.20]} \\
Y\end{array}$ \\
\hline Deal type dummies & $\mathrm{Y}$ & $\mathrm{Y}$ & Y & $\mathrm{Y}$ \\
\hline Year dummies & Y & $\mathrm{Y}$ & $\mathrm{Y}$ & $\mathrm{Y}$ \\
\hline Number of observations & 197 & 197 & 197 & 168 \\
\hline Adjusted $\mathrm{R}^{2}$ & 0.07 & 0.08 & 0.09 & 0.10 \\
\hline \multicolumn{5}{|c|}{ Panel B: Maximum PEG Board Seats } \\
\hline \multirow[t]{2}{*}{ Rule of law index } & -0.09 & -0.08 & -0.08 & -0.07 \\
\hline & {$[0.08]$} & [0.07] & {$[0.07]$} & [0.07] \\
\hline \multirow[t]{2}{*}{ British legal origins } & -0.19 & -0.18 & -0.21 & -0.22 \\
\hline & $*[0.11]$ & $*[0.12]$ & $* *[0.11]$ & $* *[0.11]$ \\
\hline \multirow[t]{2}{*}{ French legal origins } & & -0.17 & -0.12 & -0.15 \\
\hline & & $*[0.10]$ & {$[0.10]$} & [0.11] \\
\hline \multirow[t]{2}{*}{ GNP per capita } & 0.46 & 0.30 & 0.30 & 0.34 \\
\hline & $*[0.32]$ & [0.31] & {$[0.31]$} & [0.31] \\
\hline \multirow[t]{2}{*}{ U.K. or U.S. based PEG } & & & 0.39 & \\
\hline & & & $* * *[0.14]$ & \\
\hline Judicial Efficiency & & & & $\begin{array}{r}-0.59 \\
{[0.44]}\end{array}$ \\
\hline Industry dummies & Y & $\mathrm{Y}$ & Y & $\mathrm{Y}$ \\
\hline Deal type dummies & $\mathrm{Y}$ & $\mathrm{Y}$ & $\mathrm{Y}$ & $\mathrm{Y}$ \\
\hline Year dummies & $\mathrm{Y}$ & $\mathrm{Y}$ & $\mathrm{Y}$ & $\mathrm{Y}$ \\
\hline Number of observations & 197 & 197 & 197 & 168 \\
\hline Adjusted $\mathrm{R}^{2}$ & 0.06 & 0.08 & 0.10 & 0.11 \\
\hline \multicolumn{5}{|c|}{ Panel C: Maximum Founder and Manager Board Seats } \\
\hline \multirow{2}{*}{ Rule of law index } & 0.13 & 0.01 & 0.02 & 0.06 \\
\hline & [0.19] & {$[0.22]$} & {$[0.20]$} & {$[0.23]$} \\
\hline \multirow[t]{2}{*}{ British legal origins } & 0.31 & 0.31 & 0.31 & 0.74 \\
\hline & $*[0.21]$ & $*[0.21]$ & $*[0.22]$ & $* *[0.38]$ \\
\hline \multirow[t]{2}{*}{ French legal origins } & & 0.20 & 0.18 & 0.03 \\
\hline & & [0.19] & {$[0.20]$} & [0.09] \\
\hline \multirow[t]{2}{*}{ GNP per capita } & 0.15 & 0.08 & 0.09 & 0.08 \\
\hline & [0.13] & [0.17] & {$[0.17]$} & [0.16] \\
\hline \multirow[t]{2}{*}{ U.K. or U.S. based PEG } & & & 0.23 & \\
\hline & & & $* *[0.13]$ & \\
\hline Judicial Efficiency & & & & 0.62 \\
\hline
\end{tabular}




\begin{tabular}{lrrrr}
\hline \hline & & & {$[0.65]$} \\
Industry dummies & $\mathrm{Y}$ & $\mathrm{Y}$ & $\mathrm{Y}$ & $\mathrm{Y}$ \\
Deal type dummies & $\mathrm{Y}$ & $\mathrm{Y}$ & $\mathrm{Y}$ & $\mathrm{Y}$ \\
Year dummies & $\mathrm{N}$ & $\mathrm{Y}$ & $\mathrm{Y}$ & $\mathrm{Y}$ \\
Number of observations & 197 & 197 & 197 & 168 \\
Adjusted R $^{2}$ & 0.06 & 0.09 & 0.10 & 0.10 \\
\hline
\end{tabular}

$*=$ Significant at the $10 \%$ level; $* *=$ significant at the $5 \%$ level; $* * *=$ significant at the $1 \%$ level. 
Table 9-Regression analyses of supermajority provisions in developing country private equity transactions. The sample consists of 210 investments in developing countries by private equity groups (PEGs). The dependent variable is a sum of the score of supermajority provisions. (A higher score implies greater use of supermajority provisions.) Independent variables include the logarithms of an index of the rule of law and per capita gross national product, and dummy variables denoting nations with British or French legal origins and funds based in the U.K. or U.S. All regressions employ ordinary least squares specifications. Standard errors are in brackets.

\begin{tabular}{|c|c|c|c|c|}
\hline \multicolumn{5}{|c|}{ Dependent Variable: Supermajority Provision Score } \\
\hline \multirow[t]{2}{*}{ Rule of law index } & -14.35 & -20.95 & -23.67 & -26.65 \\
\hline & $* * *[7.82]$ & $* * *[9.49]$ & $* * *[9.98]$ & $* * *[10.74]$ \\
\hline \multirow[t]{2}{*}{ British legal origins } & 9.83 & 13.65 & 11.19 & 11.44 \\
\hline & $* * *[4.55]$ & $* *[6.70]$ & $* *[7.96]$ & $*[8.12]$ \\
\hline \multirow[t]{2}{*}{ French legal origins } & & & -11.06 & -11.48 \\
\hline & & & $* *[5.11]$ & $* *[5.67]$ \\
\hline \multirow[t]{2}{*}{ GNP per capita } & 3.63 & 6.01 & 5.24 & 5.96 \\
\hline & $*[2.93]$ & $*[4.86]$ & {$[4.56]$} & {$[5.02]$} \\
\hline \multirow[t]{2}{*}{ U.K. or U.S. based PEG } & & & 1.93 & \\
\hline & & & {$[4.85]$} & \\
\hline \multirow[t]{2}{*}{ Judicial Efficiency } & & & & 3.48 \\
\hline & & & & $*[2.24]$ \\
\hline Industry dummies & Y & $\mathrm{Y}$ & $\mathrm{Y}$ & $\mathrm{Y}$ \\
\hline Deal type dummies & $\mathrm{Y}$ & $\mathrm{Y}$ & $\mathrm{Y}$ & Y \\
\hline Year dummies & $\mathrm{Y}$ & $\mathrm{Y}$ & $\mathrm{Y}$ & $\mathrm{Y}$ \\
\hline Number of observations & 210 & 210 & 210 & 184 \\
\hline Adjusted $\mathrm{R}^{2}$ & 0.29 & 0.25 & 0.24 & 0.23 \\
\hline
\end{tabular}

$*=$ Significant at the $10 \%$ level; $* *=$ significant at the $5 \%$ level; $* * *=$ significant at the $1 \%$ level. 
Table 10-Regression analyses of financing size and valuation in developing country private equity transactions. The sample consists of 210 investments in developing countries by private equity groups (PEGs). The dependent variables are the logarithms of the size of the financing and the implied "postmoney" valuation of the transaction, and a dummy denoting whether the financing provides some of the capital in a follow-on transaction. Independent variables include the logarithms of sales in the year before the transaction, an index of the rule of law, and per capita gross national product, and dummy variables denoting nations with British or French legal origins and funds based in the U.K. or U.S. The financing size, valuation, and sales figures are all in millions of 1997 dollars. All regressions employ ordinary least squares specifications. Standard errors are in brackets.

\begin{tabular}{|c|c|c|c|c|}
\hline \multicolumn{5}{|c|}{ Panel A: Size of Financing } \\
\hline \multirow[t]{2}{*}{ Sales } & 0.33 & 0.34 & 0.29 & 0.34 \\
\hline & $* * *[0.08]$ & $* * *[0.09]$ & $* * *[0.10]$ & $* * *[0.11]$ \\
\hline \multirow[t]{2}{*}{ Rule of law index } & 0.85 & 0.45 & 0.48 & 0.20 \\
\hline & $*[0.49]$ & [0.49] & {$[0.43]$} & {$[0.40]$} \\
\hline \multirow[t]{2}{*}{ British legal origins } & 0.29 & 0.29 & 0.38 & 0.52 \\
\hline & {$[0.41]$} & {$[0.41]$} & {$[0.47]$} & {$[0.50]$} \\
\hline \multirow[t]{2}{*}{ French legal origins } & & 0.69 & 0.44 & 0.40 \\
\hline & & {$[0.41]$} & {$[0.41]$} & {$[0.43]$} \\
\hline \multirow[t]{2}{*}{ GNP per capita } & 0.79 & 0.56 & 0.51 & 0.37 \\
\hline & $* * *[0.34]$ & $*[0.36]$ & $*[0.36]$ & {$[0.42]$} \\
\hline \multirow[t]{2}{*}{ U.K. or U.S. based PEG } & & & 0.52 & \\
\hline & & & $* *[0.31]$ & \\
\hline Judicial Efficiency & & & & $\begin{array}{r}0.51 \\
{[0.93}\end{array}$ \\
\hline Industry dummies & Y & $\mathrm{Y}$ & $\mathrm{Y}$ & $\mathrm{Y}$ \\
\hline Deal type dummies & Y & Y & $\mathrm{Y}$ & $\mathrm{Y}$ \\
\hline Year dummies & Y & $\mathrm{Y}$ & $\mathrm{Y}$ & $\mathrm{Y}$ \\
\hline Number of observations & 193 & 193 & 193 & 172 \\
\hline Adjusted $\mathrm{R}^{2}$ & 0.33 & 0.35 & 0.35 & 0.34 \\
\hline \multicolumn{5}{|c|}{ Panel B: Implied Valuation } \\
\hline \multirow[t]{2}{*}{ Sales } & 0.38 & 0.37 & 0.38 & 0.34 \\
\hline & $* * *[0.12]$ & $* * *[0.12]$ & $* * *[0.13]$ & $* * *[0.15]$ \\
\hline \multirow[t]{2}{*}{ Rule of law index } & 1.48 & 1.08 & 0.81 & 0.84 \\
\hline & $* *[0.72]$ & $*[0.78]$ & [0.89] & [0.99] \\
\hline \multirow[t]{2}{*}{ British legal origins } & 1.85 & 2.04 & 2.47 & 1.34 \\
\hline & $* * *[0.88]$ & $* * *[0.89]$ & $* * *[0.92]$ & $*[0.97]$ \\
\hline \multirow[t]{2}{*}{ French legal origins } & & 1.06 & 1.06 & 0.84 \\
\hline & & $*[0.71]$ & $*[0.76]$ & {$[0.72]$} \\
\hline \multirow[t]{2}{*}{ GNP per capita } & 0.87 & 0.75 & 0.56 & 0.69 \\
\hline & $*[0.65]$ & {$[0.66]$} & {$[0.79]$} & {$[0.71]$} \\
\hline \multirow[t]{2}{*}{ U.K. or U.S. based PEG } & & & 0.75 & \\
\hline & & & $*[0.60]$ & \\
\hline \multirow[t]{2}{*}{ Judicial Efficiency } & & & & 3.17 \\
\hline & & & & $* * *[1.48]$ \\
\hline Industry dummies & Y & Y & Y & $\mathrm{Y}$ \\
\hline Deal type dummies & $\mathrm{Y}$ & $\mathrm{Y}$ & $\mathrm{Y}$ & $\mathrm{Y}$ \\
\hline Year dummies & $\mathrm{Y}$ & $\mathrm{Y}$ & $\mathrm{Y}$ & $\mathrm{Y}$ \\
\hline Number of observations & 193 & 193 & 193 & 172 \\
\hline Adjusted $\mathrm{R}^{2}$ & 0.40 & 0.44 & 0.45 & 0.47 \\
\hline
\end{tabular}

$*=$ Significant at the $10 \%$ level; $* *=$ significant at the $5 \%$ level; $* * *=$ significant at the $1 \%$ level. 
Table 11-Correlation matrix between different parts of private equity contracts. The sample consists of 210 investments in developing countries by private equity groups (PEGs). We regress the contract provision at the top of the column on the provisions at the beginning of each row. Each cell contains the coefficients from separate regressions of the contract provisions on the right-hand side variables (standard errors are reported in brackets). The first row in each cell reports results for the full sample, the second row reports results for UK legal origin countries only and the last row contains French and socialist legal origin countries only. We control for log of GNP, rule of law, and year, industry, deal type dummies. All variables are defined as before.

\begin{tabular}{|c|c|c|c|c|c|c|c|}
\hline \multicolumn{8}{|c|}{ Panel A: Correlation in Full Sample } \\
\hline \multirow{4}{*}{ Common stock } & Debt & Common stock & Preferred stock & Anti-dilution & $\begin{array}{l}\text { Automatic } \\
\text { conversion }\end{array}$ & $\begin{array}{l}\text { Redemption } \\
\text { rights }\end{array}$ & $\begin{array}{r}\text { PEG equity } \\
\text { stake }\end{array}$ \\
\hline & $0.08[0.04]^{* * *}$ & & & & & & \\
\hline & $0.09[0.13]$ & & & & & & \\
\hline & $0.07[0.05]^{*}$ & & & & & & \\
\hline \multirow[t]{3}{*}{ Preferred stock } & $-0.02[0.04]$ & $-0.21[0.07]^{* * *}$ & & & & & \\
\hline & $-0.02[0.12]$ & $-0.38[0.15]^{* * *}$ & & & & & \\
\hline & $-0.03[0.06]$ & $-0.01[0.09]$ & & & & & \\
\hline \multirow[t]{3}{*}{ Anti-dilution } & $-0.01[0.04]$ & $-0.25[0.07] * * *$ & $0.16[0.07]^{* * *}$ & & & & \\
\hline & $-0.05[0.03]^{* *}$ & $-0.22[0.11]^{* *}$ & $0.11[0.05]^{* * *}$ & & & & \\
\hline & $0.01[0.07]$ & $-0.09[0.13]$ & $0.13[0.12]$ & & & & \\
\hline \multirow[t]{3}{*}{ Automatic conversion } & $-0.09[0.05]^{* *}$ & $-0.50[0.07]^{* * *}$ & $0.34[0.08]^{* * *}$ & $0.43[0.07]^{* * *}$ & & & \\
\hline & $-0.18[0.09]^{* *}$ & $-0.20[0.14]^{*}$ & $0.43[0.14]^{* * *}$ & $0.85[0.15]^{* * *}$ & & & \\
\hline & $-0.07[0.07]$ & $-0.46[0.10]^{* * *}$ & $0.32[0.10]^{* * *}$ & $0.20[0.10]$ & & & \\
\hline \multirow[t]{3}{*}{ Redemption rights } & $-0.02[0.04]$ & $-0.12[0.07]^{* *}$ & $0.14[0.07]^{* * *}$ & $0.09[0.07]$ & $0.26[0.07]^{* * *}$ & & \\
\hline & $-0.04[0.10]$ & $-0.11[0.15]$ & $0.43[0.15]^{* * *}$ & $0.41[0.21]^{* *}$ & $0.30[0.15]^{* * *}$ & & \\
\hline & $0.03[0.06]$ & $-0.13[0.11]$ & $-0.07[0.08]$ & $0.07[0.07]$ & $0.12[0.07]^{* *}$ & & \\
\hline \multirow[t]{3}{*}{ PEG maximum equity stake } & $0.22[0.09]^{* * *}$ & $-0.02[0.14]$ & $0.20[0.16]$ & $0.18[0.16]$ & $-0.07[0.17]$ & $-0.16[0.17]$ & \\
\hline & $0.01[0.09]$ & $-0.50[0.45]$ & $-0.06[0.48]$ & $0.66[0.58]$ & $-0.08[0.45]$ & $-0.89[0.38]^{* * *}$ & \\
\hline & $0.51[0.15]^{* * *}$ & $-0.20[0.20]$ & $-0.03[0.24]$ & $0.13[0.19]$ & $-0.20[0.23]$ & $-0.28[0.24]$ & \\
\hline \multirow[t]{3}{*}{ Maximum board size } & $-0.03[0.08]$ & $0.04[0.15]$ & $0.38[0.15]^{* * *}$ & $0.16[0.17]$ & $0.06[0.14]$ & $-0.08[0.16]$ & $0.10[0.12]$ \\
\hline & $0.08[0.20]$ & $0.33[0.34]$ & $0.56[0.31]^{* *}$ & $0.05[0.45]$ & $0.23[0.44]$ & $0.31[0.35]$ & $-1.14[0.65]^{*}$ \\
\hline & $-0.04[0.10]$ & $0.12[0.10]$ & $0.32[0.20]^{*}$ & $0.13[0.20]$ & $-0.18[0.16]$ & $-0.21[0.22]$ & $0.23[0.31]$ \\
\hline
\end{tabular}




\begin{tabular}{|c|c|c|}
\hline \multicolumn{3}{|c|}{ Panel B: Correlation with Deal Size and Implied Valuation } \\
\hline & Deal Size & Implied Valuation \\
\hline \multirow[t]{3}{*}{ Common stock } & $-0.48[0.26]^{* *}$ & $-0.61[0.34]^{*}$ \\
\hline & $-0.53[0.54]$ & $-0.64[0.62]$ \\
\hline & $-0.56[0.35]^{*}$ & $-0.68[0.64]$ \\
\hline \multirow[t]{3}{*}{ Preferred stock } & $0.12[0.07]^{* *}$ & $-0.42[0.37]$ \\
\hline & $0.38[0.42]$ & $0.07[0.59]$ \\
\hline & $0.04[0.36]$ & $-0.75[0.61]$ \\
\hline \multirow[t]{3}{*}{ Anti-dilution } & $0.41[0.28]^{*}$ & $0.61[0.31]^{* *}$ \\
\hline & $0.96[0.31]^{* * *}$ & $1.02[0.42]^{* * *}$ \\
\hline & $0.11[0.47]$ & $0.43[0.79]$ \\
\hline \multirow[t]{3}{*}{ Automatic conversion } & $0.27[0.28]$ & $0.20[0.40]$ \\
\hline & $1.19[0.37]^{* * *}$ & $1.17[0.51]^{* * *}$ \\
\hline & $-0.07[0.38]$ & $-0.79[0.63]$ \\
\hline \multirow[t]{3}{*}{ Redemption rights } & $0.13[0.24]$ & $0.03[0.37]$ \\
\hline & $0.15[0.45]$ & $0.51[0.56]$ \\
\hline & $0.13[0.34]$ & $-0.12[0.58]$ \\
\hline \multirow[t]{3}{*}{ PEG maximum equity stake } & $1.25[0.56]^{* * *}$ & $1.68[0.94]^{*}$ \\
\hline & $1.49[1.00]^{*}$ & $1.06[1.64]$ \\
\hline & $1.07[0.81]$ & $-2.76[1.23]^{* * *}$ \\
\hline \multirow[t]{3}{*}{ Maximum board size } & $2.05[0.48]^{* * *}$ & $1.69[0.53]^{* * *}$ \\
\hline & $2.28[1.05]^{* * *}$ & $1.89[0.74]^{* * *}$ \\
\hline & $1.77[0.64]^{* * *}$ & $0.92[0.95]$ \\
\hline
\end{tabular}




\section{Average Market Capitalization of Listed Firms 1990-2000}

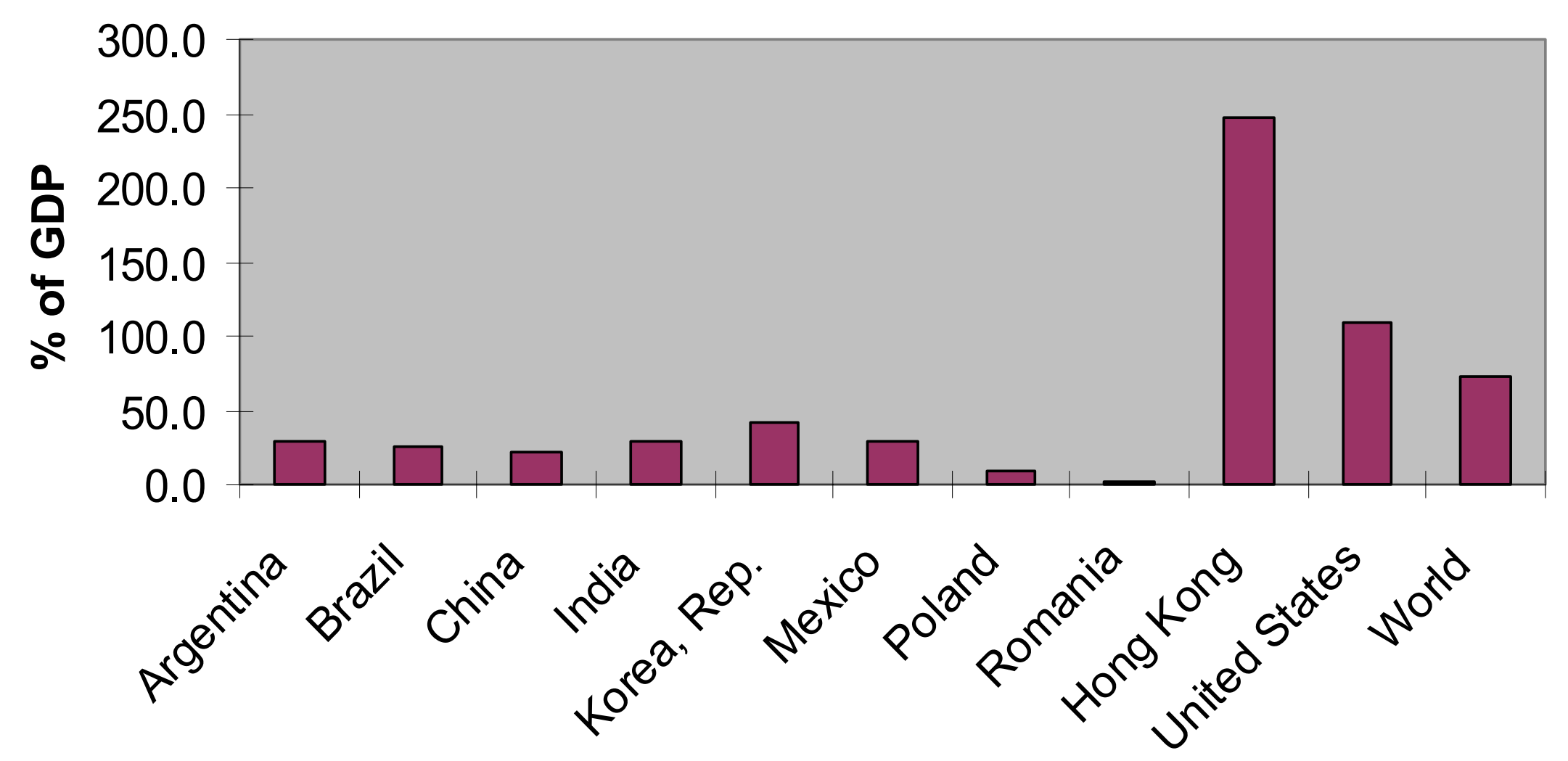


Appendix: Key legal provisions affecting private equity investors in nine nations most frequently represented in the sample.

\begin{tabular}{|c|c|c|c|c|c|c|c|c|c|}
\hline $\begin{array}{l}\text { Class of } \\
\text { Limitation }\end{array}$ & Argentina & Brazil & Hong Kong & India & Mexico & $\begin{array}{l}\text { People's Republic of } \\
\text { China }\end{array}$ & Poland & Republic of Korea & Romania \\
\hline Security Type & $\begin{array}{l}\text { No restrictions, but } \\
\text { preferred stock can } \\
\text { only have same } \\
\text { vote as common } \\
\text { stock. Also possible } \\
\text { to have common } \\
\text { stock with enhanced } \\
\text { voting rights (up to } 5 \\
\text { votes). }\end{array}$ & No restrictions. & No restrictions. & $\begin{array}{l}\text { Preferred stocks } \\
\text { cannot have any } \\
\text { voting rights, } \\
\text { except in special } \\
\text { circumstances. } \\
\text { Limits on extent of } \\
\text { returns preferred } \\
\text { shareholders can } \\
\text { enjoy. }\end{array}$ & $\begin{array}{l}\text { No restrictions, but } \\
\text { some limitations } \\
\text { on voting rights of } \\
\text { preferred } \\
\text { shareholders. }\end{array}$ & $\begin{array}{l}\text { Most domestic and } \\
\text { foreign private equity } \\
\text { investments must } \\
\text { employ common stock- } \\
\text { like structure. Some } \\
\text { large investments may } \\
\text { use other securities, but } \\
\text { must receive authorities' } \\
\text { permission first. }\end{array}$ & $\begin{array}{l}\text { No restrictions, but } \\
\text { limitations on } \\
\text { voting (no more } \\
\text { than } 2-3 x \text { common } \\
\text { stock), dividend, } \\
\text { and liquidation } \\
\text { preference rights } \\
\text { of preferred } \\
\text { shareholders. }\end{array}$ & $\begin{array}{l}\text { No restrictions, but } \\
\text { only common } \\
\text { stock had voting } \\
\text { rights until late } \\
\text { 1990s. Now, no } \\
\text { restrictions. }\end{array}$ & $\begin{array}{l}\text { No restrictions, but } \\
\text { investors cannot } \\
\text { require that } \\
\text { classes of } \\
\text { shareholders vote } \\
\text { as a block. }\end{array}$ \\
\hline $\begin{array}{l}\text { Super-Majority } \\
\text { Provisions }\end{array}$ & No restrictions. & No restrictions. & $\begin{array}{l}\text { No restrictions. } \\
\text { Many corporate } \\
\text { events require } \\
\text { approval of } 75 \% \text { of } \\
\text { shareholders. }\end{array}$ & $\begin{array}{l}\text { No restrictions. } \\
\text { Some corporate } \\
\text { events require } \\
\text { approval of } 75 \% \text { of } \\
\text { shareholders. }\end{array}$ & $\begin{array}{l}\text { No restrictions. } \\
\text { Some legal } \\
\text { protections for } \\
\text { minority } \\
\text { shareholders (e.g., } \\
\text { right to name at } \\
\text { least one director). }\end{array}$ & $\begin{array}{l}\text { No restrictions. Some } \\
\text { corporate events must } \\
\text { have } 2 / 3 \text { rd approval by } \\
\text { investors. For foreign } \\
\text { investments, decisions } \\
\text { must be approved by } \\
2 / 3 \text { rds of directors in } \\
\text { many cases. }\end{array}$ & $\begin{array}{l}\text { No restrictions. } \\
\text { Some corporate } \\
\text { events must have } \\
75 \% \text { approval by } \\
\text { investors. }\end{array}$ & No restrictions. & No restrictions. \\
\hline $\begin{array}{l}\text { Management } \\
\text { Equity Holdings }\end{array}$ & $\begin{array}{l}\text { No restrictions. } \\
\text { Ambiguities } \\
\text { surround tax } \\
\text { treatment of } \\
\text { options. }\end{array}$ & $\begin{array}{l}\text { Limitations on types of } \\
\text { firms who can issue } \\
\text { stock options. Special } \\
\text { disclosure requirements } \\
\text { for option-issuing firms. } \\
\text { Disadvantageous tax } \\
\text { treatment of options. }\end{array}$ & $\begin{array}{l}\text { No restrictions, } \\
\text { except that } \\
\text { shareholders in } \\
\text { private firms must } \\
\text { first offer shares to } \\
\text { other investors. }\end{array}$ & $\begin{array}{l}\text { No restrictions on } \\
\text { private firms. }\end{array}$ & No restrictions. & $\begin{array}{l}\text { For most investments, } \\
\text { not possible to issue } \\
\text { equity to management. } \\
\text { May be allowed in } \\
\text { certain very large } \\
\text { investments, but } \\
\text { permission of authorities } \\
\text { may be required. }\end{array}$ & No restrictions. & No restrictions. & No restrictions. \\
\hline $\begin{array}{l}\text { Reinvestment } \\
\text { and Anti-Dilution } \\
\text { Provisions }\end{array}$ & $\begin{array}{l}\text { Equity holders can } \\
\text { maintain pro rata } \\
\text { share. Provision } \\
\text { can be waived with } \\
\text { shareholder vote. }\end{array}$ & $\begin{array}{l}\text { Equity holders can } \\
\text { maintain pro rata share. } \\
\text { Restrictions on } \\
\text { unreasonably dilutive } \\
\text { financings. }\end{array}$ & $\begin{array}{l}\text { Equity holders can } \\
\text { maintain pro rata } \\
\text { share. }\end{array}$ & $\begin{array}{l}\text { Equity holders can } \\
\text { maintain pro rata } \\
\text { share. Provision } \\
\text { can be waived with } \\
\text { shareholder vote. }\end{array}$ & $\begin{array}{l}\text { Equity holders can } \\
\text { maintain pro rata } \\
\text { share. Provision } \\
\text { can be waived with } \\
\text { shareholder vote. }\end{array}$ & $\begin{array}{l}\text { Equity holders have pre- } \\
\text { emptive right to purchase } \\
\text { shares, except for certain } \\
\text { very large investments. }\end{array}$ & $\begin{array}{l}\text { Equity holders can } \\
\text { maintain pro rata } \\
\text { share. Provision } \\
\text { can be waived with } \\
80 \% \text { shareholder } \\
\text { vote. }\end{array}$ & $\begin{array}{l}\text { Equity holders } \\
\text { have pre-emptive } \\
\text { right to purchase } \\
\text { shares, with limited } \\
\text { exceptions. }\end{array}$ & $\begin{array}{l}\text { Equity holders } \\
\text { have pre-emptive } \\
\text { right to purchase } \\
\text { shares, except for } \\
\text { some private firms. }\end{array}$ \\
\hline Domiciling Entity & $\begin{array}{l}\text { Could be domiciled } \\
\text { overseas until } \\
\text { recently. Now } \\
\text { substantial } \\
\text { difficulties to do so. }\end{array}$ & $\begin{array}{l}\text { Can be domiciled } \\
\text { overseas, but may be } \\
\text { more difficult to enforce } \\
\text { corporate rights locally. }\end{array}$ & $\begin{array}{l}\text { Can be domiciled } \\
\text { overseas. }\end{array}$ & $\begin{array}{l}\text { Can be domiciled } \\
\text { overseas. }\end{array}$ & $\begin{array}{l}\text { Can be domiciled } \\
\text { overseas. }\end{array}$ & $\begin{array}{l}\text { Cannot be domiciled } \\
\text { overseas. }\end{array}$ & $\begin{array}{l}\text { Can be domiciled } \\
\text { overseas. }\end{array}$ & $\begin{array}{l}\text { Can be domiciled } \\
\text { overseas. May } \\
\text { entail loss of } \\
\text { attractive tax } \\
\text { incentives for start- } \\
\text { ups. }\end{array}$ & $\begin{array}{l}\text { These restrictions } \\
\text { cannot be avoided } \\
\text { by domiciling } \\
\text { company in } \\
\text { another country. }\end{array}$ \\
\hline
\end{tabular}

